\title{
GEOLOGICAL SURVEY OF CANADA RADIOCARBON DATES VII
}

\author{
J. A. LOWDON and W. BLAKE, JR.* \\ Geological Survey of Canada, Ottawa, Canada
}

\section{INTRODUCTION}

The 2-L counter (GSC I) and the 5-L counter (GSC IV) were operated routinely during the past year. The 5-L counter was operated at $1 \mathrm{~atm}$, except for February-March 1967, when it was operated at $4 \mathrm{~atm}$. Approximately half the determinations reported were obtained from each counter.

Age calculations are based on a $\mathrm{C}^{14}$ half-life of $5568 \pm 30 \mathrm{yr}$ and 0.95 of the activity of the NBS oxalic-acid standard. Ages are quoted in yr before 1950. Age errors include: counting errors of sample, background, and standard; error in the half-life of $\mathrm{C}^{14}$; and an error term to account for the average variation of $\pm 1.5 \%$ in the $\mathrm{C}^{14}$ concentration of the biosphere during the past $1100 \mathrm{yr}$. No ages are quoted with a standard deviation of less than $\pm 100 \mathrm{yr}$. Finite ages are based on the $2 \sigma$ criterion and "Infinite" ages on the $4 \sigma$ criterion (GSC II). All age calculations have been carried out by a C.D.C. 3100 computer, instead of the I.B.M. 1620 reported in RAdIOCARBon, vol. 9.

Slight changes have been made in preparation and purification tech-

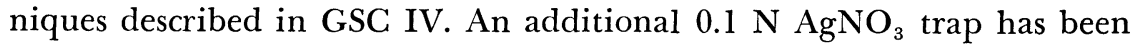
inserted in the purification line; this has saved time in purification of samples. The laboratory now dates only the collagen fraction of bone samples.

Average background and standard counting rates over the past 12 months are listed in Tables 1 and 2. The monthly average background count is made up of 4 individual daily counts (except for MarchApril, 1967, in the 2-L counter, where the average is that of 8 counts, and February-March, 1967, in the 5-L counter, where the average is made up of 9 individual counts). During the 12-month period 10 different background preparations were counted in the 2-L counter, and 11 in the 5-L counter. Not one of the counts was rejected, for statistical or other reasons.

* The introductory part of this paper has been prepared by the first author, who operates the laboratory. The date list has been compiled by the second author from descriptions of samples and interpretations of dates by the collectors. 
TABLE 1

Monthly Background (c/m) for Period

October 1, 1966 to September 30, 1967

\begin{tabular}{lcr}
\hline \multicolumn{1}{c}{ Month } & $\begin{array}{c}2-\mathrm{L} \text { counter } \\
(2 \mathrm{~atm})\end{array}$ & $\begin{array}{c}\text { 5-L counter } \\
(1 \mathrm{~atm})\end{array}$ \\
\hline October 1966 & $1.317 \pm .025$ & $2.266 \pm .038$ \\
November & $1.311 \pm .024$ & $2.207 \pm .042$ \\
December & $1.225 \pm .045$ & $2.160 \pm .024$ \\
January 1967 & $1.239 \pm .020$ & $2.123 \pm .024$ \\
February & $1.263 \pm .021$ & \multirow{2}{*}{$* 2.905 \pm .033$} \\
March & $1.249 \pm .016$ & $2.135 \pm .030$ \\
April & $1.181 \pm .019$ & $2.200 \pm .026$ \\
May & $1.211 \pm .019$ & $2.194 \pm .025$ \\
June & $1.179 \pm .026$ & $2.125 \pm .030$ \\
July & $1.170 \pm .019$ & $2.106 \pm .025$ \\
August & $1.170 \pm .023$ & $2.129 \pm .024$ \\
September & &
\end{tabular}

* 5-L counter operating at 4 atm.

The standard counting rates (see Table 2) are the monthly averages of 3 individual daily counts (except for March-April in the 2-L counter, and February-March in the 5-L counter, where the average of 2 months is used.) Seven different oxalic-acid preparations were counted in the 2-L counter and 6 in the 5-L counter. One of the standards for the 5-L counter was rejected (April) because the result fell outside the maximum statistical error.

TABLE 2

Monthly Standard, $\mathrm{N}_{\mathrm{o}}{ }^{*},(\mathrm{c} / \mathrm{m})$ for Period

October 1, 1966 to September 30, 1967

\begin{tabular}{|c|c|c|}
\hline Month & $\begin{array}{l}2-\mathrm{L} \text { counter } \\
\quad\left(\begin{array}{ll}2 & \mathrm{~atm}\end{array}\right)\end{array}$ & $\begin{array}{l}5 \text {-L counter } \\
(1 \mathrm{~atm})\end{array}$ \\
\hline October 1966 & $19.888 \pm .145$ & $28.776 \pm .122$ \\
\hline November & $20.021 \pm .174$ & $28.944 \pm .119$ \\
\hline December & $20.159 \pm .103$ & $29.079 \pm .117$ \\
\hline January 1967 & $20.208 \pm .100$ & $29.011 \pm .101$ \\
\hline February & $20.161 \pm .099$ & \\
\hline March & & \}$* * 112.085 \pm .244$ \\
\hline April & $20.139 \pm .082$ & $28.951 \pm .123$ \\
\hline May & $20.058 \pm .099$ & $28.862 \pm .120$ \\
\hline June & $20.280 \pm .097$ & $28.990 \pm .118$ \\
\hline July & $20.210 \pm .231$ & $29.034 \pm .126$ \\
\hline August & $20.057 \pm .156$ & $29.250 \pm .118$ \\
\hline September & $20.030 \pm .090$ & $29.103 \pm .119$ \\
\hline
\end{tabular}

$* \mathrm{~N}_{\mathrm{o}}=0.95 \times$ net counting rate of the NBS oxalic-acid standard.

**5-L counter operating at $4 \mathrm{~atm}$. 
Tests for $\mathrm{C}^{14}$ contamination in shell samples were continued as shown in parts $\mathrm{A}$ and $\mathrm{B}$ of Table 3.

Table 3

Tests for $\mathrm{C}^{14}$ Contamination*

\begin{tabular}{|c|c|c|c|}
\hline & Sample No. & Fraction & $\begin{array}{c}\text { Age } \\
\text { (yr B.P.) }\end{array}$ \\
\hline \multicolumn{4}{|c|}{ A. Marine Shells } \\
\hline & GSC-110 & $21-100 \% * *$ & $8160 \pm 140$ \\
\hline & GSC-110-2 & $51-100$ & $8090 \pm 160$ \\
\hline & \multirow[t]{2}{*}{ GSC-667 } & $21-60$ & $26,700 \pm 450$ \\
\hline & & $61-100$ & $27,790 \pm 480$ \\
\hline & \multirow[t]{2}{*}{ GSC-695 } & 21-60 & $>30,000$ \\
\hline & & $61-100$ & $>38,000$ \\
\hline & \multirow[t]{2}{*}{ GSC-787 } & 21-60 & $33,800 \pm 900$ \\
\hline & & $61-100$ & $42,400 \pm 1900$ \\
\hline \multirow[t]{3}{*}{ B. } & \multicolumn{3}{|l|}{ Fresh Water Shells } \\
\hline & \multirow[t]{2}{*}{ GSC-689 } & $21-60$ & $10,700 \pm 160$ \\
\hline & & $61-100$ & $10,900 \pm 150$ \\
\hline \multirow[t]{8}{*}{ C. } & \multicolumn{3}{|c|}{ Marl and Organic Detritus } \\
\hline & \multirow[t]{3}{*}{ GSC-384 } & Inorganic (Marl) & $12,190 \pm 160$ \\
\hline & & Organic & $9580 \pm 220$ \\
\hline & & Inorganic $\quad($ Marl $) \dagger$ & $4820 \pm 140$ \\
\hline & \multirow[t]{2}{*}{ GSC-657 } & Inorganic (Marl) & $13,200 \pm 170$ \\
\hline & & Organic & $13,800 \pm 170$ \\
\hline & \multirow[t]{2}{*}{ GSC-675 } & Inorganic (Marl) & $12,100 \pm 170$ \\
\hline & & Organic & $11,500 \pm 180$ \\
\hline
\end{tabular}

* Detailed descriptions of all samples appear in this date list except for GSC-657, 675 , and 689 .

** Two separate preparations were made on shells from the same sample.

$\dagger$ In this second preparation, from another bag of submitted sample, carbonate sand grains were removed by sieving.

Part C, of Table 3, illustrates the results obtained from different fractions of the same sample.

After many futile attempts to construct a 1-L counter with a lower background count than the present 2-L counter, the GSC Instrument Shop has fabricated one which, on preliminary testing, gives a background of ca. $1.10 \mathrm{c} / \mathrm{m}$ and a net modern count of ca. $6.00 \mathrm{c} / \mathrm{m}$. Further information will be published in a future edition of RADIOCARBON.

\section{ACKNOWLEDGMENTS}

Thanks are extended to Ian M. Robertson and David Hodgkin for assistance in the preparation and measurement of samples in the laboratory, and to Gretchen Minning for assistance in compilation of the date list. 


\section{SAMPLE DESCRIPTIONS}

\section{GEOLOGIC SAMPLES}

\section{A. Eastern Canada}

\section{GSC-598. St. George's Bay, Newfoundland}

$$
13,420 \pm 190
$$

Marine pelecypod shell fragments (Macoma sp. ?) from sea cliff $0.7 \mathrm{mi} \mathrm{SW}$ of mouth of Highlands R., St. George's Bay, Newfoundland (48 $11^{\prime} \mathrm{N}$ Lat, $58^{\circ} 54.5^{\prime} \mathrm{W}$ Long), at alt ca. $18 \mathrm{ft}$. Shells coll. $2 \mathrm{ft}$ above base of blue-black massive silty clay overlying red-brown compact till with sharp contact, and overlain by red-brown silt and clay rhythmites believed to be bottomset beds of marine delta. Alt of delta surface ca. 50 $\mathrm{ft}$, but marine limit higher as delta surface is terraced. Coll. 1964 by I. A. Brookes, York Univ., Toronto. Comment (I.A.B.): date gives age of early part of marine submergence following deposition of underlying till.

\section{GSC-461. Sable Island, Nova Scotia}

$$
210 \pm 130
$$

Plant detritus from soil horizon, exposed in dune blow-out at low tide level on NW beach of Sable Island, Nova Scotia $\left(43^{\circ} 56^{\prime} \mathrm{N}\right.$ Lat, $60^{\circ} 02^{\prime} \mathrm{W}$ Long). Coll. 1965 from fresh exposure by N. James and D. J. Stanley, Dalhousie Univ., Halifax; subm. by J. Terasmae.* Comment (J.T.): date indicates recent, relatively stable episode with soil formation, followed by erosion and dune-sand accumulation. Pollen assemblages from this soil horizon indicate vegetation similar to modern plant communities on Sable Island. NaOH-leach omitted from sample pretreatment.

\section{GSC-791. 'Salmon River Lake,' Nova Scotia}

$5540 \pm 140$ 3590 в.c.

Lake mud from 2.60 to $2.80 \mathrm{~m}$ depth in core coll. with piston sampler under $2 \mathrm{~m}$ of water in deepest part of 'Salmon River Lake,' Richmond County, Cape Breton Island, Nova Scotia (45 $38^{\prime} 40^{\prime \prime}$ N Lat, $60^{\circ} 46^{\prime} 30^{\prime \prime}$ W Long), at alt ca. $140 \mathrm{ft}$. Coll. 1955 by D. A. and B. G. R. Livingstone, Duke Univ., Durham, North Carolina. Comment (D.A.L.): date is first from hemlock maximum on Cape Breton Island. $\mathrm{NaOH}$ leach omitted from sample pretreatment.

\section{'Silver Lake' series, Nova Scotia}

Samples coll. with piston corer in sediments under $2.75 \mathrm{~m}$ of water in deepest part of Silver Lake, Halifax County, Nova Scotia (43 $33^{\prime}$ 48" N Lat, $63^{\circ} 38^{\prime} 34^{\prime \prime}$ W Long). Coll. 1955 by D. A. Livingstone.

GSC-792. 'Silver Lake', 2.35 to $2.60 \mathrm{~m}$

* All persons referred to as collectors or submitters of samples or cited as sources of data are with the Geological Survey of Canada unless otherwise specified. 
GSC-772. 'Silver Lake', 3.50 to $3.67 \mathrm{~m}$

$7140 \pm 140$

Lake mud from 3.50 to $3.67 \mathrm{~m}$ depth in core.

5190 в.c.

General Comment (D.A.L.): GSC-772 and GSC-792 date lower and upper boundaries, respectively, of hemlock zone (Livingstone and Estes, 1967; Livingstone, in press); together with GSC-791 (5540 \pm 140 , this list) they suggest this zone was contemporaneous with C-1 hemlock in Maine and S New England. Maximum abundance of hemlock pollen appears to have been deposited during latter part of C-1 time in a S New England sense. NaOH-leach omitted from pretreatment of both samples.

GSC-695. Cape St. Mary, Nova Scotia $>38,000$

Marine shells from stony clay in sea cliff $1 \mathrm{mi}$ SE of Cape St. Mary,

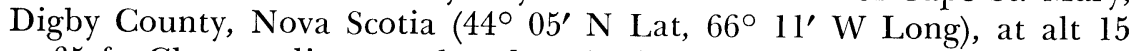
to $35 \mathrm{ft}$. Clay overlies gravel and underlies cemented, N-dipping, glaciofluvial gravel, surface of which has been reworked by postglacial marine action up to 40 to $45 \mathrm{ft}$. Shell species (id. by F. J. E. Wagner) are comparable to those of area today and unlike postglacial cold-water forms of opposing New Brunswick shore and of Gulf of St. Lawrence. Coll. 1966 by D. R. Grant. Two fractions were dated:

outer fraction (21-60\% leach), two 1-day counts $>30,000$

inner fraction (61-100\% leach), one 3-day count $>38,000$ Comment (D.R.G.): shell-bearing stony clay is interpreted as till deposited by glacier lobe that flowed from W or NW (from St. Mary's Bay) toward S end of Nova Scotia; shells were picked up from sea bottom.

\section{GSC-775. East Baltic Bog, Prince Edward Island $\quad \mathbf{8 4 3 0} \pm 150$}

Gyttja from depth 574 to $578 \mathrm{~cm}$ at base of peat-sediment sequence overlying sand in E Baltic Bog, alt $140 \mathrm{ft}, 8 \mathrm{mi} \mathrm{E}$ of Souris, Prince Edward Island (46 $24^{\prime} 30^{\prime \prime} \mathrm{N}$ Lat, $62^{\circ} 09^{\prime} \mathrm{W}$ Long). Sample obtained with a GSC piston corer (Mott, 1966). Coll. 1966 by T. W. Anderson. Comment (T.W.A.): sample (in Pollen Zone Al; Deevey, 1958) dates beginning of organic accumulation in bog. $\mathrm{NaOH}$-leach omitted from sample pretreatment.

\section{GSC-793. Mermaid Lake Bog, Prince $8630 \pm 180$ \\ Gy. Mermaid Lake Bog, Prince Edward Island 6680 B.c.}

Gyttja coll. with a GSC piston corer from depth 276 to $280 \mathrm{~cm}$ at base of peat-sediment sequence in Mermaid Lake Bog, alt $<50 \mathrm{ft}, 6 \mathrm{mi}$ $\mathrm{NE}$ of Charlottetown, Prince Edward Island $\left(46^{\circ} 15^{\prime} \mathrm{N}\right.$ Lat, $63^{\circ} 01^{\prime} 30^{\prime \prime}$ W Long). Gyttja is underlain by sand. Coll. 1966 by T. W. Anderson. Comment (T.W.A.): sample (in pollen zone Al) dates beginning of organic accumulation in bog. $\mathrm{NaOH}-\mathrm{leach}$ omitted from sample pretreatment.

\section{GSC-773. Portage Bog, Prince Edward Island}

$9880 \pm 150$

Gyttja coll. with a GSC piston corer from depth 623 to $628 \mathrm{~cm}$ at 
base of peat-sediment sequence in Portage Bog, alt $<25 \mathrm{ft}, 1 \mathrm{mi}$ NNW of Portage, Prince Edward Island $\left(46^{\circ} 40^{\prime} 25^{\prime \prime} \mathrm{N}\right.$ Lat, 64 $04^{\circ} 30^{\prime \prime} \mathrm{W}$ Long). Gyttja is underlain by pebbly sand. Coll. 1966 by T. W. Anderson. Comment (T.W.A.): sample (in pollen zone L3) dates beginning of organic accumulation in bog. $\mathrm{NaOH}$-leach omitted from sample pretreatment.

\section{GSC-795. Sand Point, New Brunswick}

$12,300 \pm 160$

Marine shells in silt bed ca. $50 \mathrm{ft}$ above high tide level, overlying coarse gravel of kame-terrace sequence and overlain by cross-bedded fluvial or deltaic gravel, $\mathrm{E}$ side of St. Croix R., $5 \mathrm{mi} \mathrm{N}$ of river mouth on Passamaquoddy Bay in St. Andrew's, New Brunswick (45 08 $30^{\prime \prime}$ $\mathrm{N}$ Lat, $67^{\circ} 07^{\prime} 45^{\prime \prime} \mathrm{W}$ Long). Locality is $20 \mathrm{mi} \mathrm{NNW}$ of Lubec, Maine, at $\mathrm{E}$ end of Cherryfield-Eastport moraine system and is NW of its projection to St. John (Borns, 1967). Site discovered by J. Welsted, Brandon Univ., Brandon, Manitoba, 1966. Coll. by N. R. Gadd, 1967. Comment (N.R.G.): marine clay is intercalated between ice-contact strata and younger fluvial or deltaic beds probably related to offlap conditions; apparently clay was deposited during maximum post-last-glaciation marine submergence; date should closely approximate age of that event. Date based on one 3-day count.

GSC-655. Sutton, Quebec

$>28,000$

Wood fragment from sand folded and faulted by ice thrusting in proximal part of glacial delta extending across valley of Sutton R., $2.2 \mathrm{mi} \mathrm{SW}$ of RR sta. at Sutton, Quebec $\left(45^{\circ} 05^{\prime} 20^{\prime \prime} \mathrm{N}\right.$ Lat, $72^{\circ} 39^{\prime} 10^{\prime \prime}$ W Long), at alt ca. $625 \mathrm{ft}$. Delta deposited in Fort Ann phase of Glacial Lake Vermont, which sample was expected to date. Coll. 1966 by R. Doak; subm. by J. A. Elson, McGill Univ., Montreal. Comment (J.A.E.): wood is older fossil material probably glacially transported; it may represent St. Pierre nonglacial interval although it was not compressed as is most plant matter from St. Pierre beds. NaOH-leach omitted from sample pretreatment. Sample mixed with dead gas for counting.

GSC-419. St. Hilaire, Quebec

$12,570 \pm 220$

10,620 в.c.

Plant detritus in silt from $29 \mathrm{ft}$ below surface of bog (alt $850 \mathrm{ft}$ ) on St. Hilaire Mt., $3 \mathrm{mi}$ E of St. Hilaire Sta., Quebec (45 $33^{\prime} 30^{\prime \prime} \mathrm{N}$ Lat, $73^{\circ} 08^{\prime} 30^{\prime \prime} \mathrm{W}$ Long). Coll. 1965 with 2-in GSG piston corer by $\mathrm{P}$. Lasalle, Dept. of Natural Resources, Quebec, and J. Terasmae. Comment (J.T.): date is minimum for deglaciation of SW part of St. Lawrence Lowland (cf. Lasalle, 1966). NaOH-leach omitted from sample pretreatment. Sample mixed with dead gas for counting.

\section{GSC-482. Lac Hertel, Quebec}

$10,880 \pm 260$

Silty gyttja from 776 to $790 \mathrm{~cm}$ depth beneath water/sediment interface in Lac Hertel on St. Hilaire Mt., $0.5 \mathrm{mi} \mathrm{N}$ of St. Hilaire village, 
Quebec (45 $32^{\prime} 45^{\prime \prime} \mathrm{N}$ Lat, $73^{\circ} 09^{\prime} \mathrm{W}$ Long). Coll. 1965 with Livingstone piston corer by J. Terasmae and P. Lasalle. Comment (J.T.): date is minimum for isolation of lake basin (present lake alt $566 \mathrm{ft}$ ) from Champlain Sea in St. Lawrence Lowland; also supports validity of date on marine shells at alt $298 \mathrm{ft}$ on St. Hilaire Mt. (Y-1558, 10,560 \pm 160 ; Lasalle, 1966; Terasmae and Lasalle, 1968). NaOH-leach omitted from sample pretreatment. Sample mixed with dead gas for counting.

\section{GSC-680. Kazabazua, Quebec}

$$
9910 \pm 200
$$

$\mathbf{7 9 6 0}$ в.c.

Gyttja from 8.95 to $9.05 \mathrm{~m}$ depth below bog surface in kettle in sand plain (alt ca. $600 \mathrm{ft}$ ), $2.2 \mathrm{mi} \mathrm{W}$ of Kazabazua, Quebec (45 $57^{\prime} \mathrm{N}$ Lat, 76 04' W Long). Coll. 1966 with 2-inch GSC piston corer by J. Terasmae. Comment (J.T.): date is minimum for sand plain in Gatineau R. valley, $\mathrm{N}$ of Ottawa, and gives age for early-postglacial Picea maximum in pollen diagram from this locality. $\mathrm{NaOH}$-leach omitted from sample pretreatment. Sample mixed with dead gas for counting.

\section{GSC-681. Mer Bleue Bog, Ottawa, Ontario (II)}

$7650 \pm 210$

Gyttja from 515 to $525 \mathrm{~cm}$ depth below surface of bog (alt 225

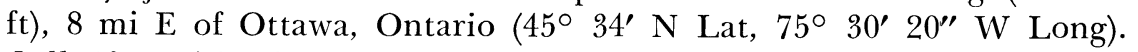
Coll. 1966 with 2-inch GSC piston corer by J. Terasmae. Comment (J.T.): date is minimum for abandonment of an ancient Ottawa $\mathrm{R}$. channel (cf. GSC-548, $6750 \pm$ 150, GSC VI). NaOH-leach omitted from sample pretreatment. Sample mixed with dead gas for counting.

\section{Atkins Lake series, Ontario}

Samples of bottom sediments in Atkins Lake (alt $381 \mathrm{ft}$, water depth $65 \mathrm{~cm}$ ), $11 \mathrm{mi} \mathrm{S}$ of Merrickville, Ontario $\left(44^{\circ} 45^{\prime} \mathrm{N}\right.$ Lat, $75^{\circ} 51^{\prime} \mathrm{W}$ Long). Coll. 1966 with Livingstone piston corer by T. W. Anderson and M. Ouelett; subm. by J. Terasmae.

\section{GSC-807. Atkins Lake, 134 to $147 \mathrm{~cm}$}

$1020 \pm 160$

Gyttja from 134 to $147 \mathrm{~cm}$ depth below lake level.

\section{GSC-762. Atkins Lake, 441 to $453 \mathrm{~cm}$}

\section{$11,100 \pm 270$ 9150 в.c.}

Gyttja from 441 to $453 \mathrm{~cm}$ depth below lake level.

General Comment (J.T.): GSC-762 is minimum age of westernmost limit reached by Champlain Sea NW of Brockville. GSC-807 dates change from dark-brown to black gyttja, and nearly coincides with upper peak zone of Tsuga and rise of Picea graph in pollen record. NaOH-leach omitted from pretreatment of both samples. Both samples mixed with dead gas for counting. Date GSC-762 based on one 3-day count. 


\section{GSC-765. Grady Lake, Ontario}

$10,500 \pm 180$

8550 в.c.

Gyttja from 13.46 to $13.57 \mathrm{~m}$ depth below lake level (alt $563 \mathrm{ft}$; water depth $325 \mathrm{~cm}$ ) in Grady Lake, $3 \mathrm{mi}$ NNE of Westport, Ontario ( $44^{\circ} 43^{\prime} \mathrm{N}$ Lat, $76^{\circ} 22^{\prime} 30^{\prime \prime} \mathrm{W}$ Long). Coll. 1966 with Livingstone piston corer by R. J. Mott and M. Ouellet; subm. by J. Terasmae. Comment (J.T.): date is minimum for deglaciation of this area $\mathrm{N}$ of Dummer Moraine (cf. GSC-649, 11,180 \pm 180 , this list) and gives age of Picea peak in pollen record. NaOH-leach omitted from sample pretreatment. Sample mixed with dead gas for counting.

\section{GSC-742. Northeastern Lake Ontario}

$8790 \pm 170$

Gyttja beneath clay at alt $50 \mathrm{~m}(165 \mathrm{ft})$ from local basin in NE Lake Ontario, alt $74.5 \mathrm{~m}$ (245 ft), between Galloo and Little Galloo Islands, New York (43 53.1' N Lat, $76^{\circ} 24.8^{\prime} \mathrm{W}$ Long). Basin closure is ca. $6 \mathrm{~m}(20 \mathrm{ft})$. Sample is segment of gyttja underlying $49 \mathrm{~cm}$ noncalcareous clay and overlying firm calcareous clay. Coll. 1966 with gravity corer $(3.5 \mathrm{~cm}$ I.D.) by C. F. M. Lewis. Comment (C.F.M.L.): gyttja considered a pond deposit, indicating Lake Ontario was then at least $17 \mathrm{~m}$ $(55 \mathrm{ft})$ lower; Galloo Island area was more widely exposed subaerially than at present. Date approximates low-level Admiralty phase of Lake Ontario and is maximal for subsequent flooding of site (Lewis and McNeely, 1967) by differential uplift of lake outlet at head of St. Lawrence R. NaOH-leach omitted from sample pretreatment. Sample mixed with dead gas for counting.

\section{GSC-649. Little Round Lake, Ontario}

$11,180 \pm 180$ 9230 B.c.

Silty gyttja from 19.01 to $19.06 \mathrm{~m}$ depth below lake level (alt 675 $\mathrm{ft}$; water depth at coring site, $15.8 \mathrm{~m}$ ) in Little Round Lake, $2 \mathrm{mi} \mathrm{N}$ of Sharbot Lake, Ontario (44 $47^{\prime} 20^{\prime \prime} \mathrm{N}$ Lat, $76^{\circ} 41^{\prime} 30^{\prime \prime} \mathrm{W}$ Long). Coll. 1966 by R. J. Mott and R. N. McNeely with Livingstone piston corer. Comment (J. Terasmae): date is minimum for ice retreat from Dummer Moraine, a major glacial feature WNW of Kingston, Ontario (cf. GSC-765, $10,500 \pm 180$, this list). NaOH-leach omitted from sample pretreatment. Sample mixed with dead gas for counting. Date based on one 3-day count.

\section{GSC-625. Ross Lake, Ontario}

$11,350 \pm 260$ 9400 B.c.

Silty gyttja from 32.8 to $33.1 \mathrm{ft}$ depth below lake level (alt $463 \mathrm{ft}$; water depth $18 \mathrm{ft}$ ) in Ross Lake, $5 \mathrm{mi} \mathrm{N}$ of Foxboro, Ontario $\left(44^{\circ} 19^{\prime}\right.$ $\mathrm{N}$ Lat, $77^{\circ} 27^{\prime} 30^{\prime \prime} \mathrm{W}$ Long). Coll. 1966 with Livingstone piston corer by J. Terasmae. Comment (J.T.): date is minimum for end of Lake Iroquois stage in Lake Ontario basin (cf. GSC-679, 11,020 \pm 170 , and GSC-626, $11,760 \pm 310$, this list.) $\mathrm{NaOH}$-leach omitted from sample pretreatment. Sample mixed with dead gas for counting. 


\section{GSC-679. Oak Lake, Ontario}

$11,020 \pm 170$

Sandy gyttja from 55.8 to $56.1 \mathrm{ft}$ depth below lake level (alt $668 \mathrm{ft}$; water depth at coring site $37 \mathrm{ft}$ ) in Oak Lake, $2.5 \mathrm{mi}$ SE of Stirling, Ontario (44 $16^{\prime} \mathrm{N}$ Lat, $77^{\circ} 31^{\prime} 30^{\prime \prime} \mathrm{W}$ Long). Coll. 1966 in 2-inch Shelby tube by J. Terasmae. Comment (J.T.): date is minimum for end of Lake Iroquois stage here (cf. GSC-625, 11,350 \pm 260 and GSC-626, $11,760 \pm 310$, this list). NaOH-leach omitted from sample pretreatment. Date based on one 3-day count.

\section{GSC-626. Biddy Lake, Ontario}

$11,760 \pm 310$

9810 B.C.

Gyttja from 46.2 to $46.5 \mathrm{ft}$ depth below lake level (alt $566 \mathrm{ft}$; water depth $29 \mathrm{ft}$ ) in Biddy Lake, $4 \mathrm{mi} \mathrm{NE}$ of Colborne, Ontario $\left(44^{\circ} 03^{\prime} \mathrm{N}\right.$ Lat, $77^{\circ} 49^{\prime} 30^{\prime \prime} \mathrm{W}$ Long). Coll. 1966 with Livingstone piston corer by J. Terasmae. Comment (J.T.): date is minimum for end of Lake Iroquois stage here (cf. GSC-625, 11,350 \pm 260 and GSC-679, 11,020 \pm 170 , this list). Biddy Lake was isolated from glacial lake by a bay-mouth bar. $\mathrm{NaOH}-\mathrm{leach}$ omitted from sample pretreatment. Sample mixed with dead gas for counting.

\section{GSC-638. North Bay, Ontario}

$9820 \pm 200$

Gyttja from 4.6 to $4.7 \mathrm{~m}$ depth below lake level (alt $1025 \mathrm{ft}$; water depth $1.25 \mathrm{~m}$ ) in small unnamed pond $2 \mathrm{mi} \mathrm{N}$ of North Bay, Ontario $\left(46^{\circ} 21^{\prime} \mathrm{N}\right.$ Lat, $79^{\circ} 28^{\prime} \mathrm{W}$ Long). Coll. 1965 with Hiller peat borer by J. Terasmae. Comment (J.T.): date is minimum for ice retreat from North Bay and opening of this outlet E from Great Lakes (cf. Terasmae and Hughes, 1960), and agrees with bog bottom date from same area (S-100, $9570 \pm 150$, Saskatchewan III). NaOH-leach omitted from sample pretreatment. Sample mixed with dead gas for counting.

\section{GSC-670. Iroquois Falls, Ontario}

$7560 \pm 180$

Silty gyttja from 500 to $510 \mathrm{~cm}$ depth below sediment/water interface in '19 Mile Lake' (alt ca. $850 \mathrm{ft}$ ), $19 \mathrm{mi} \mathrm{N}$ of Iroquois Falls, Ontario $\left(49^{\circ} 01^{\prime} \mathrm{N}\right.$ Lat, $80^{\circ} 36^{\prime} \mathrm{W}$ Long). Coll. 1965 by T. W. Anderson with Livingstone piston corer; subm. by J. Terasmae. Comment (J.T.): date is minimum for final drainage of Glacial Lake Barlow-Ojibway in $\mathbf{N}$ Ontario and postdates Cochrane ice readvance (cf. GSC-487, $7660 \pm 140$, and GSC-309, $7150 \pm 140$, both in GSC V; GSC-624, $7380 \pm 140$, GSC VI). NaOH-leach omitted from sample pretreatment. Sample mixed with dead gas for counting.

\section{GSC-620. Walker Pond, Ontario}

$12,190 \pm 230$

Gyttja from 16.0 to $16.13 \mathrm{~m}$ depth below lake level (alt $900 \mathrm{ft}$; water depth $10 \mathrm{~m})$ in Walker Pond, $2 \mathrm{mi}$ SE of London, Ontario $\left(42^{\circ} 57^{\prime} \mathrm{N}\right.$ 
Lat, $81^{\circ} 13^{\prime} \mathrm{W}$ Long). Coll. 1965 with Livingstone piston corer by J. Terasmae. Comment (J.T.): date is minimum for ice retreat from Ingersoll Moraine and Lake Maumee stage. $\mathrm{NaOH}$-leach omitted from sample pretreatment. Sample mixed with dead gas for counting. Date based on one 3-day count.

\section{GSC-611. Thamesville, Ontario}

$11,380 \pm 170$

\section{0 в.C.}

Mastodon bones from E side gravel pit in Kent Co., Camden Twp.,

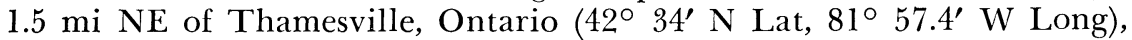
at alt ca. $620 \mathrm{ft}$. Sample excavated by drag line from fresh exposure, at $6 \mathrm{ft}$ depth. Scattered bones occur near base of 3-ft section of gravel and in underlying fine sediments; gravel is overlain by alluvium with shells and wood. Coll. 1965 by B. Tinline for A. Dreimanis, Univ. of Western Ontario, London. Comment (A.D.): gravel is probably alluvial deposit of early Thames $R$. rather than deltaic deposit of river in Lake Lundy or Lake Grassmere, as date appears too young for these lakes. Collagen fraction used for dating.

\section{GSC-614. Ferguson Farm, Tupperville, Ontario}

$8910 \pm 150$

Mastodon bones from J. Ferguson farm, Chatham Tp., con. 14, 1t. 10, $2 \mathrm{mi}$ SSW of Tupperville, Ontario $\left(42^{\circ} 33.9^{\prime} \mathrm{N}\right.$ Lat, $82^{\circ} 17.3^{\prime} \mathrm{W}$ Long), at alt ca. $585 \mathrm{ft}$. Bones exposed by excavation along $\mathrm{N}$ side of drainage ditch in slight depression in lacustrine sediments. Bones are at base of gyttja and peat, underlain successively by marl and lacustrine clay, both with molluscs. Coll. 1954 by A. Dreimanis. Comment (A.D.): date, which agrees with pollen diagram from site, suggests non-sedimentation and exposure of bones for ca. 2500 yrs, because gyttja from cavities within mastodon skull is $6230 \pm 240 \mathrm{yr}$ old (S-16, Saskatchewan II; Dreimanis, 1961; 1967). Collagen fraction used for dating. Date based on one 3-day count.

\section{GSC-384. Roddick Township, Ontario}

$9580 \pm 220$

\section{B.C.}

Carbonaceous material in marl exposed in gully ca. $1 \mathrm{ft}$ deep at bottom of beach-ridge gravel pit, NE corner sec. 27, Roddick Tp., Rainy R. District, ca. $5 \mathrm{mi}$ SW of Fort Frances, Ontario (48 $33^{\prime} \mathrm{N}$ Lat, $93^{\circ} 29^{\prime}$ W Long), at alt ca. $1140 \mathrm{ft}$. Originally sand and gravel overlay sandy marl rich in aquatic snail shells, marl containing carbonized plant fragments, and sandy till. Johnston (1915) interpreted gravel beach as Campbell strandline of Lake Aggasiz; marl probably formed in lagoon across which beach advanced. Coll. 1964 by J. A. Elson, McGill Univ., Montreal. Three determinations were made:

inorganic portion (bulk sample, untreated)

$$
\begin{array}{r}
12,190 \pm 160 \\
9580 \pm 220 \\
4820 \pm 140
\end{array}
$$$$
\text { portion dissolved in phosphoric acid) }
$$$$
\text { inorganic portion (fine fraction only, after sieving }
$$$$
\text { marl in second bag of submitted sample) }
$$ 
Comment (J.A.E.): sample was intended to check validity of marl dates in this part of Lake Agassiz Basin; cf. GSC-383 (10,600 \pm 150 , GSC VI), a marl date in agreement with dates on wood on $\mathrm{W}$ side of basin. It was thought marl as a whole, which contained sand, might have ancient carbonate grains derived from Paleozoic rocks, but that fine fraction would be uncontaminated. Bulk sample of marl appears to contain grains of ancient carbonates as anticipated. Probably fine fraction has received younger carbonate from ground water which percolated freely through overlying beach sand and gravel. Carbonaceous matter gives date for Lake Agassiz compatible with many others (e.g., W-1057, $9200 \pm 600$, USGS VII: Elson, 1967). NaOH-leach omitted from pretreatment of organic fraction; sample mixed with dead gas for counting.

\section{B. Western Canada}

\section{Zelena Series, Manitoba}

Samples from lacustrine silt and marl separating surface till from underlying till, in road cut on $\mathrm{E}$ side of Shell $\mathrm{R}$. valley, ca. $1 \mathrm{mi} \mathrm{N}$ and $3 \mathrm{mi} \mathrm{E}$ of Zelena, Manitoba, NW 1/4 sec. 17, tp. 28, rge. 27, W prin. mer. (51 $24^{\prime} \mathrm{N}$ Lat, $101^{\circ} 14^{\prime} \mathrm{W}$ Long). Coll. 1966 by R. W. Klassen.

GSC-653. Zelena, Manitoba, charcoal

Charcoal from silt above marl zone.

GSC-711. Zelena, Manitoba, marl
$37,700 \pm 1500$ 35,750 в.c.

$28,220 \pm 380$ 26,270 B.c. General Comment (R.W.K.): apparent age difference of charcoal and marl probably due to contamination of marl by modern carbon. More reliable charcoal date suggests maximum age for silt; inter-till beds can probably be correlated with deposits of redefined Port Talbot Interstade in Lake Erie region (Klassen, 1967; Dreimanis et al; 1966). No sample pretreatment for GSC-711; date based on one 3-day count. NaOH-leach omitted from sample pretreatment for GSC-653.

\section{Shellmouth, Manitoba series}

Wood samples exposed by damsite excavation at base of $\mathrm{E}$ wall of Assiniboine R. valley, $3.75 \mathrm{mi} \mathrm{NE}$ of Shellmouth, Manitoba, NE $1 / 4$ sec 1 , tp. 23, rge. 29 , W prin. mer. (50 $58^{\prime} \mathrm{N}$ Lat, $101^{\circ} 24^{\prime} \mathrm{W}$ Long). Coll. 1966 by R. W. Klassen.

\section{GSC-677. Shellmouth, Manitoba (I)}

$$
10,690 \pm 190
$$

Wood from top of alluvial silt beneath till slump block and ca. $10 \mathrm{ft}$ above flood plain.

GSC-678. Shellmouth, Manitoba (II)

Wood from alluvial sand beneath 200 to $250 \mathrm{ft}$ of drift including at least 3 tills, and overlying bedrock. 
General Comment (R.W.K.): date GSC-677 is minimum for development of Assiniboine R. valley. Sand containing wood on which date GSC-678 was obtained is interpreted as interglacial deposit within preglacial valley, here crossed by Assiniboine R. valley. Due to a computer error, date was reported as $>42,600$ (Klassen, 1967). Date GSC-678 based on one 4-day count.

\section{GSC-756. Roblin, Manitoba}

$2760 \pm 130$

Wood from borehole in Assiniboine R. flats ca. $8 \mathrm{mi} \mathrm{SW}$ of Roblin, Manitoba, SW $1 / 4$ sec. 35 , tp. 24 , rge. 29 , W prin. mer. $\left(51^{\circ} 07^{\prime} \mathrm{N}\right.$ Lat, $101^{\circ} 26^{\prime}$ W Long). Coll. 1966 by R. W. Klassen. Comment (R.W.K.): sample believed from 40 to $50 \mathrm{ft}$ level in river alluvium but young date indicates near-surface source. Sample mixed with dead gas for counting. Date based on one 3-day count.

\section{GSC-750. Dropmore, Manitoba}

Wood from 280 to $310 \mathrm{ft}$ in borehole ca. $0.75 \mathrm{mi} \mathrm{S}$ of Dropmore, Manitoba, SE $1 / 4$ sec. 27 , tp. 23 , rge. 29 , W prin. mer. $\left(51^{\circ} 01^{\prime} \mathrm{N}\right.$ Lat, $101^{\circ} 27^{\prime} \mathrm{W}$ Long). Sand and gravel unit in which wood occurs is at 243 to $328 \mathrm{ft}$ depth and underlies at least 3 tills. Coll. 1966 by R. W. Klassen. Comment (R.W.K.): sand and gravel may be subsurface equivalent of exposed unit from which GSC-678 (>41,000, this list) was taken.

\section{GSC-676. Makaroff, Manitoba}

$>\mathbf{3 4 , 0 0 0}$

Wood fragments and organic debris from upper surface of varved clay and basal zone of overlying till ca. $1 \mathrm{mi} \mathrm{E}$ and $2 \mathrm{mi} \mathrm{N}$ of Makaroff, Manitoba, NE $1 / 4$ sec. 27 , tp. 27 , rge. $29, \mathrm{~W}$ prin. mer $\left(51^{\circ} 23^{\prime} \mathrm{N}\right.$ Lat, $101^{\circ}$ $29^{\prime}$ W Long). Varved clay up to $4 \mathrm{ft}$ thick is underlain by stony silt and overlain by 2 tills. Units are exposed in road cut in terrace along $\mathbf{E}$ side of Big Boggy Creek. Coll. 1966 by R. W. Klassen. Comment (R.W.K.): date records nonglacial interval preceding at least last 2 glaciations in this region. Due to a computer error, date was reported as $>42,600$ (Klassen, 1967).

\section{GSC-790. Spring Valley, Saskatchewan}

Peaty muck from SE-dipping layers or lenses within silty-clayey beds overlain by brownish till, exposed in roadside cut $3 \mathrm{mi} \mathrm{SE}$ of Spring Valley, Saskatchewan $\left(49^{\circ} 49^{\prime} \mathrm{N}\right.$ Lat, $105^{\circ} 22^{\prime} \mathrm{W}$ Long), at alt ca. 2600 $\mathrm{ft}$. Sample is from uppermost of 3 organic layers, in hummocky terrain, within The Dirt Hills ice-thrust moraine. Coll. 1965 by V. K. Prest. Comment (V.K.P.): uncompressed peat believed related to other occurrences of buried organic materials in this region (cf. Parizek, 1964; also GSC-618, 10,710 \pm 250 , GSC VI); these occur within and beneath glacial drift that slumped as dead ice melted, in postglacial time, to produce markedly hummocked and kettled surface. "Old" age of GSC-790 indicates presence of older sediments within ice-thrust moraine; pollen studies suggest sediments are Pleistocene. NaOH-leach omitted from sample pretreatment. 
GSC-761. Bridgeford, Saskatchewan

$1460 \pm 140$

Plant detritus beneath $10 \mathrm{ft}$ sand in Qu'Appelle Valley, ca. $4 \mathrm{mi} \mathrm{N}$ of Bridgeford, Saskatchewan, NE 1/4 sec. 24, tp. 23, rge 4, W 3rd mer. $\left(50^{\circ} 58^{\prime} \mathrm{N}\right.$ Lat, $106^{\circ} 26^{\prime} \mathrm{W}$ Long). Coll. 1966 by R. W. Klassen. Comment (R.W.K.): material coll. to determine rate of sediment accumulation in divide area of abandoned valley. Young date suggests probable eolian origin for sand. NaOH-leach omitted from sample pretreatment. Sample mixed with dead gas for counting. Date based on one 3-day count.

\section{Medicine Hat series, Alberta (II)}

\section{GSC-780. 'Mitchell Bluff'}

Wood fragment coll. during excavation for bones on knoll at NW end 'Mitchell Bluff,' $\mathrm{S}$ bank of South Saskatchewan R., $6 \mathrm{mi} \mathrm{N}$ of Medicine Hat, Alberta; NE 1/4 sec. 32, tp. 13, rge. 5, W 4th mer. $\left(50^{\circ} 07^{\prime} 45^{\prime \prime}\right.$ $\mathrm{N}$ Lat, $110^{\circ} 38^{\prime} 40^{\prime \prime} \mathrm{W}$ Long) at alt ca. $2200 \mathrm{ft}$. Wood was $3 \mathrm{ft}$ below surface in gravel and sand with extensive mammal fauna and chert fragments possibly worked by man. Coll. 1966 by C. S. Churcher, Royal Ontario Mus., Toronto, and L. M. Kisko. Comment (A.M. Stalker): date is minimum for mammal fauna and chert fragments. NaOH-leach omitted from sample pretreatment. Sample mixed with dead gas for counting. Date based on one 3-day count.

\section{GSC-704. 'Island Bluff'}

Bison bones from $\mathrm{W}$ side of gully tributary to NE bank North Saskatchewan R., at 'Island Bluff' section ca. $7 \mathrm{mi} \mathrm{N}$ of Medicine Hat, Alberta, SW 1/4 sec. 4, tp. 14, rge. 5, W 4th mer. $\left(50^{\circ} 08^{\prime} 30^{\prime \prime} \mathrm{N}\right.$ Lat, $110^{\circ}$ $38^{\prime} 30^{\prime \prime}$ W Long). Bones, at alt ca. $2250 \mathrm{ft}$, were ca. $120 \mathrm{ft}$ above river and $150 \mathrm{ft}$ below prairie level. Bones from site previously id. as Bison occidentalis (?) and considered older than topographically higher classical Wisconsin till sheets (Westgate, 1965). Material dated because bones appeared too fresh for age suggested and inclosing deposits were unlike others at same level. Coll. 1966 by C. S. Churcher. Comment (A. M. Stalker): date confirms that inclosing material is slumped, and throws doubt on reported presence of Bison occidentalis (?). Sample mixed with dead gas for counting. Date based on one 1-day count.

\section{GSC-802. 'Mitchell Bluff' and 'Island Bluff'}

$5540 \pm 250$

Combined sample from 'Mitchell Bluff' (NE 1/4 sec. 32, tp. 19, rge. 5, W 4th mer.; $50^{\circ} 07^{\prime} 45^{\prime \prime} \mathrm{N}$ Lat, $110^{\circ} 38^{\prime} 40^{\prime \prime} \mathrm{W}$ Long) and 'Island Bluff' (SW $1 / 4$ sec. 4, tp. 14, rge. 5 , W 4 th mer.; $50^{\circ} 08^{\prime} 20^{\prime \prime} \mathrm{N}$ Lat, $110^{\circ}$ $38^{\prime} 30^{\prime \prime}$ W Long), at alt ca. $2200 \mathrm{ft}$. Sample consisted of bone coll. from same bed of sand and gravel on both banks of South Saskatchewan R., ca. $100 \mathrm{ft}$ above river and beneath 60 to $180 \mathrm{ft}$ drift, mostly till. Source bed contained mammals and worked (?) chert fragments. Coll. 1966 by 
C. S. Churcher and L. M. Kisko. Comment (A. M. Stalker): sample expected to be beyond range of dating; reason for young age is not known. However, during preparation for identification, bones were washed in Gelva (Code \#V15, Shawinigan Chemicals of Canada), an organic compound; this is probable source of contamination. GSC-780 ( $>30,000$, this list) came from same bed at 'Mitchell Bluff' and is thought a better indication of age of sand and gravel. Sample mixed with dead gas for counting. Date based on one 3-day count.

\section{GSC-805. 'Lindoe Bluff'}

$11,200 \pm 200$

Bone, chiefly bison and horse, from 'Lindoe Bluff' on $\mathrm{W}$ bank of South Saskatchewan R. 2 mi N of Medicine Hat, Alberta, W 1/2 sec. 17 , tp. 13 , rge. 5, W 4 th mer. (50 $04^{\prime} 50^{\prime \prime} \mathrm{N}$ Lat, $110^{\circ} 39^{\prime} 20^{\prime \prime} \mathrm{W}$ Long), at alt ca. $2175 \mathrm{ft}$. Bones were in gravel laid down when river bed was 25 to 50 feet above present level. Coll. 1966 by C. S. Churcher. Comment (A. M. Stalker): date gives age of abundant mammal fauna at site and indicates South Saskatchewan R. incised rapidly immediately following last glaciation, but downcutting soon slowed. Sample mixed with dead gas for counting.

\section{GSC-728. Taber, Alberta}

$35,980 \pm 1060$ 34,030 в.c.

Small pieces of oxidized wood from alluvial sand at 'Rattlesnake Bluff,' E bank Oldman R., 8 mi NNE of Taber, Alberta, SE 1/4 sec. 24, tp. 11, rge. 16, W 4th mer. (49 $55^{\prime} 30^{\prime \prime} \mathrm{N} \mathrm{Lat,} 112^{\circ} 04^{\prime} \mathrm{W}$ Long), at alt ca. $2450 \mathrm{ft}$. Wood found scattered, where it had been washed into place, ca. $10 \mathrm{ft}$ above base of sand bed, overlying till and preglacial(?) gravel and overlain by 4 tills. Coll. 1961 by A. M. Stalker. Comment (A.M.S.): the 4 tills appear to be Classical Wisconsin. Sample mixed with dead gas for counting.

\section{GSC-803. Fort Macleod, Alberta}

$\mathbf{5 4 1 0} \pm \mathbf{3 0 0}$

Bison bone from Head's-Smashed-In Buffalo Jump ca. $10 \mathrm{mi} \mathrm{W}$ of Fort Macleod, Alberta, NE $1 / 4$ sec. 6, tp. 9, rge. 27, W 4th mer. $\left(49^{\circ}\right.$ $42^{\prime} 40^{\prime \prime} \mathrm{N}$ Lat, $113^{\circ} 38^{\prime} 45^{\prime \prime}$ W Long), at alt ca. $3475 \mathrm{ft}$. Source of sample was Layer 38 in archeological Test Pit z, $27.6 \mathrm{ft}$ below original surface and above large bedrock block that had slid E $100 \mathrm{ft}$ from nearby cliff. Coll. 1966 by B. Reeves, Univ. of Calgary, Calgary; subm. by A. M. Stalker. Comments (B.R.): date is earliest yet obtained for any buffalo jump in Northern Plain; (A.M.S.): date is minimum for occurrence of bedrock slide and dates time of occupation of Layer 38. Sample mixed with dead gas for counting. Date based on one 3-day count.

\section{Castle River series, Alberta (II)}

Samples from 'Mountain Mill Bluff' on S Bank Castle R., ca. $6 \mathrm{mi}$ $\mathrm{W}$ of town of Pincher Creek, Alberta in SE $1 / 4$ sec. 21, tp. 6, rge. 1, W 
5th mer. (49 $29^{\prime} \mathrm{N}$ Lat, $114^{\circ} 03^{\prime} 30^{\prime \prime} \mathrm{W}$ Long). Coll. 1966 by A. M. Stalker. Section shows Cordilleran outwash overlain by stream and wind deposits, including 3 buried soils of which lowest is thickest and best developed. Previous samples in this series (cf. GSG VI) include GSC447 (6150 \pm 140 , bison jaw) and GSC-490 (6100 \pm 180 , bison teeth).

\section{GSC-705. Castle River, bison bone}

Bison bone from gravel and coarse sand outwash, ca. $30 \mathrm{ft}$ above river, alt ca. $3800 \mathrm{ft}$.

\section{GSC-741. Castle River, shells}

Terrestrial-gastropod shells from alluvial or eolian sand ca. $75 \mathrm{ft}$ above river and ca. $45 \mathrm{ft}$ above outwash that yielded bison bones for GSC-447, GSC-490, and GSC-705, alt ca. 3850 ft. Shells came from in and just below middle buried soil ca. $5 \mathrm{ft}$ above lowest (main) buried soil.

\section{GSC-743. Castle River, charcoal}

Charcoal from approx. same site as shells of GSC-741.

730 B.C.

General Comment (A.M.S.): GSC-705 came from approx. same spot as GSC-447 and GSC-490 (6150 \pm 140 and $6100 \pm 180$, respectively; GSC VI). It was dated to check these 2 dates, which were younger than expected. It appears to substantiate them. GSC-741 and GSC-743 were run partly to check earlier dates. Ca. $3000 \mathrm{yr}$ interval between dates from outwash and those from near middle buried soil allows abundant time for deposition of intervening beds and formation of thick, lowest, buried soil. In addition, GSC-741 and GSC-743 give minimum time for development of lowest buried soil and maximum for development of middle soil horizon. The 700-yr difference between GSC-741 and GSC-743 is disconcerting, particularly as latter was, if anything, stratigraphically lower. Reason for difference is not known. GSC-741 mixed with dead gas for counting. Date for GSC-705 based on one 3-day count.

\section{GSC-767. Duffield, Alberta}

$$
8320 \pm 140
$$

Wood from top of river gravel in abandoned meander of North Saskatchewan R., N of Duffield, Alberta (52 $25^{\prime} 33^{\prime \prime} \mathrm{N}$ Lat, $114^{\circ} 16^{\prime}$ $38^{\prime \prime} \mathrm{W}$ Long), $<10 \mathrm{ft}$ above river. Gravel overlies bedrock and is overlain by clay, and marl with woody peat. Coll. 1966 by L. V. Hills, Univ. of Calgary, Calgary. Comment (L.V.H.): date confirms earlier date of 8150 \pm 100 yr (S-106, Saskatchewan III) on wood at base of marl, and indicates that during last $8300 \mathrm{yr}$ downcutting by North Saskatchewan R. has been slow. Date based on one 4-day count.

$4850 \pm 130$

GSC-752. Goose Creek Basin, Alberta

2900 B.C.

Peat $180 \mathrm{~cm}$ below surface inside "Prairie mound"-type feature $\mathrm{N}$ 
of Goose Lake, Alberta (54 $22^{\prime} 30^{\prime \prime} \mathrm{N}$ Lat, $115^{\circ} 06^{\prime} \mathrm{W}$ Long), at alt ca. $2475 \mathrm{ft}$. Coll. 1966 with Hiller sampler by D. A. St-Onge. Comment (D.S.): date indicates that considerable time elapsed between drainage of glacial lake (phase of Glacial Lake Edmonton?) from area and start of organic accumulation in depression. Date based on one 3-day count.

\section{GSC-674. Iosegun River Basin, Alberta}

$4150 \pm 140$

Basal peat $320 \mathrm{~cm}$ below surface between Iosegun R. and Atikamek Creek, Alberta (54 $34^{\prime} \mathrm{N}$ Lat, $116^{\circ} 48^{\prime} \mathrm{W}$ Long), at alt. ca. $2450 \mathrm{ft}$. Coll. 1965 with Hiller sampler by D. A. St-Onge. Comment (D.S.): dates start of accumulation of organic debris in this part of basin of Glacial Lake Rycroft (cf. GSC-551, $6590 \pm 150$, GSC VI). NaOH-leach omitted from sample pretreatment.

\section{GSC-673. Marsh Head Creek, Alberta}

$8530 \pm 170$ 6580 B.C.

Basal peat $270 \mathrm{~cm}$ below surface, overlying sand, in valley of Marsh Head Creek, Alberta (54 $13^{\circ} \mathrm{N}$ Lat, $116^{\circ} 55^{\prime} \mathrm{W}$ Long), at alt ca. 2940 ft. Coll. 1965 with Hiller sampler by D. A. St-Onge. Comment (D.S.): valley was occupied by Little Smoky $R$. draining $E$ into Athabasca $R$. when northward drainage was blocked by ice. Date is minimum for abandonment of valley segment by Little Smoky R.; however, dates from deltaic deposits in Glacial Lake Rycroft (GSC-508, 12,190 \pm 350 , GSG VI; GSC-694, 13,510 \pm 230 and GSC-698, 13,580 \pm 260; this list) indicate that considerable time elapsed before organic debris started to accumulate. $\mathrm{NaOH}$-leach omitted from sample pretreatment. Sample mixed with dead gas for counting. Date based on one 3-day count.

\section{Little Smoky River series, Alberta}

Fresh-water gastropod shells in sand in road cut, South Kaybobs Oilfield, Alberta (54 $21^{\prime} \mathrm{N}$ Lat, $117^{\circ} 01^{\prime} \mathrm{W}$ Long), at alt ca. $2700 \mathrm{ft}$. Coll. 1966 by D. A. St-Onge.

\section{GSC-694. Little Smoky River, large shells}

$13,510 \pm 230$

Large clean shells hand-picked out of sample.

\section{1,560 в.с.}

\section{GSC-698. Little Smoky River, small shells}

$13,580 \pm 260$

Small shells partly filled with calcareous silt from same sample as GSC-694.

General Comment (D.S.): identical dates indicate that small amount of calcareous silt had no influence on sample age in this locality. Sample is from same locality, but 3 to $5 \mathrm{ft}$ lower in section than GSC-508 (12,190 \pm 350, GSC VI); dates sedimentation in Glacial Lake Rycroft (cf. StOnge, 1967). Sample GSC-694 mixed with dead gas for counting. Each date based on one 3-day count. 


\section{GSC-768. Marlboro, Alberta}

$8830 \pm 150$

6880 B.C.

Marl from $4 \mathrm{ft}$ below surface on $\mathrm{N}$ side of lake, ca. $3 \mathrm{mi} \mathrm{E}$ of Marlboro, Alberta, in LSD 14, sec. 6, tp. 53, rge. 19, W 5th mer. $\left(53^{\circ} 33^{\prime} 30^{\prime \prime}\right.$ $\mathrm{N}$ Lat, $116^{\circ} 43^{\prime} 30^{\prime \prime} \mathrm{W}$ Long), at alt $3000+\mathrm{ft}$. Marl was completely saturated. Sample from hole dug to depth $4 \mathrm{ft}$; roots of surface vegetation penetrate to this depth. In places marl is overlain by organic material; it is underlain by outwash derived from last Cordilleran glacier. Coll. 1966 by M. A. Roed, Edmonton, Alberta. Comment (M.A.R.): date is minimum for deglaciation (cf. dates on Glacial Lake Rycroft from Little Smoky River valley, ca. $55 \mathrm{mi} \mathrm{N}$ of Marlboro: GSC508, 12,190 \pm 350, GSC VI; GSC-694, 13,510 \pm 230 and GSC-694, 13,580 \pm 260 , this list).

\section{Banff National Park series, Alberta}

Charcoal from loess deposits on kame complex exposed along North Saskatchewan R. SW of highway bridge across river in Banff National Park, Alberta ( $51^{\circ} 58^{\prime} \mathrm{N}$ Lat, $116^{\circ} 43^{\prime} \mathrm{W}$ Long). Coll. 1965 by A. Dreimanis.

\section{$2120 \pm 150$ \\ GSC-577. Banff National Park, charcoal (upper) 170 B.c.}

Charcoal from 2 charcoal-rich lenses in loess, ca. $3 \mathrm{ft}$ below surface and 0 to 4 in. above "upper continuous volcanic ash layer." Ash is underlain successively by loess, "lower continuous volcanic ash layer," loess, and glaciofluvial gravel. Site is $450 \mathrm{ft} \mathrm{SW}$ of highway bridge.

\section{GSC-531. Banff National Park, charcoal (lower) 720 B.c.}

Charcoal (single charred piece of wood) from loess, ca. $3 \mathrm{ft}$ below surface and 1 to 2 in. below "upper continuous volcanic ash layer." Loess bed is underlain successively by "lower continuous volcanic ash layer," loess with at least 1 buried soil underlain by charcoal $(9330 \pm$ $170 \mathrm{yr}$ old, GSC-332, GSC V), loess and fine sand with rock fragments, and glaciofluvial gravel. Site is $300 \mathrm{ft} \mathrm{SW}$ of highway bridge.

General Comment (A.D.): mineralogical, chemical, and textural investigations id. "upper continuous volcanic ash layer" as Bridge R. ash (Westgate and Dreimanis, 1967). Dates bracketing time of deposition agree with GSC-529, $2440 \pm 140$ (this list; also see Nasmith et al., 1967), a date on peat immediately below Bridge R. ash in Jesmond Bog, British Columbia. NaOH-leach omitted from sample pretreatment of GSC-531. Date GSC-577 based on one 3-day count.

\section{GSC-719. Leviathan Lake, British Columbia}

$$
10,270 \pm 190
$$

Peat from base of 190-cm-thick bog at W edge of Leviathan Lake, $1 \mathrm{mi} \mathrm{E}$ of mouth of Campbell Creek, $\mathrm{E}$ side of Kootenay Lake, $3.5 \mathrm{mi}$ $\mathrm{NE}$ of Kaslo, British Columbia $\left(49^{\circ} 57^{\prime} 00^{\prime \prime} \mathrm{N}\right.$ Lat, $116^{\circ} 51^{\prime} 15^{\prime \prime} \mathrm{W}$ 
Long). Coll. 1966 with Hiller peat borer by R. J. Fulton. Comment (R.J.F.): date is minimum for establishment of vegetation following deglaciation (Fulton, in press). Sample mixed with dead gas for counting.

\section{Meadow Creek series, British Columbia}

Wood and peat from borrow pit on $\mathrm{E}$ side of Meadow Creek, 1.5 mi W of Duncan Lake dam and $6 \mathrm{mi} \mathrm{N}$ of Kootenay Lake, British Columbia $\left(50^{\circ} 15^{\prime} \mathrm{N}\right.$ Lat, $116^{\circ} 59^{\prime} \mathrm{W}$ Long). Pit exposes till overlying nonglacial sediments which overlie a paleosol developed on a 2nd till. Nonglacial sediments are overbank and channel deposits separated into 3 units, in ascending order: 1) silt and gravel, 2) topset gravel and sand, and 3) intermixed sand, gravel, and silt. Paleosol is exposed below upper 2 units but slopes underneath exposure of interstratified silt and gravel (Fulton, in press). Coll. 1965 and 1966 by R. J. Fulton.

\section{GSC-740. Meadow Creek (I)}

$43,800 \pm 800$

Root in growth position $265 \mathrm{~cm}$ below top of interstratified silt and gravel. Sample is lowermost dated. Date based on one 1-day and one 3-day count in 5-L counter at $4 \mathrm{~atm}$.

GSC-720. Meadow Creek (II)

$42,300 \pm 700$

Peat $60 \mathrm{~cm}$ below top of interstratified silt and gravel. Date based on two 1-day counts and one 3-day count in 5-L counter at $4 \mathrm{~atm}$.

GSC-733. Meadow Creek (III)

$41,900 \pm 600$

39,950 в.c.

Roots from upper $10 \mathrm{~cm}$ of paleosol. Date based on one 5-day count in 5 - $\mathrm{L}$ counter at $4 \mathrm{~atm}$.

GSC-716. Meadow Greek (IV)

$41,800 \pm 600$

Stump rooted in paleosol and buried by topset gravel and sand. Two determinations were made:

in 2-L counter (one 1-day count)

$>36,000$

in 5-L counter at $4 \mathrm{~atm}$ (one 3-day count and one 1-day count)

$$
41,800 \pm 600
$$

GSC-542. Meadow Creek (V)

$\mathbf{3 3 , 7 0 0} \pm \mathbf{3 0 0}$

Wood from silt band within intermixed sand, gravel, and silt unit, $75 \mathrm{~cm}$ above paleosol and $30 \mathrm{~cm}$ above bed of volcanic ash. Two determinations were made:

in 2-L counter (one 1-day count)

in 5-L counter at $4 \mathrm{~atm}$ (three 1-day counts)

$35,700 \pm 1500$

$33,700 \pm 300$

GSC-493. Meadow Creek (VI)

$32,710 \pm 800$

30,760 в.c.

Wood from a silt bed within intermixed sand, gravel, and silt unit, $195 \mathrm{~cm}$ above paleosol. 
GSC-715. Meadow Creek (VII)

Wood from gravel at top of intermixed sand, gravel, and silt unit, $1 \mathrm{~m}$ below upper till. Date based on one 3-day count.

General Comment (R.J.F.): sequence of dates from apparently conformable series of sediments indicates that this part of British Columbia was not occupied by ice from at least ca. 44,000 yr B.P. until after ca. 26,000 yr B.P.; previously, peat from $40 \mathrm{ft}$ depth in borehole at Duncan Lake damsite was dated at $>39,700$ (GSC-219, GSC IV). This nonglacial interval corresponds to Olympia Interglaciation of Armstrong et al. (1965).

\section{Nakimu Caves series, British Columbia}

Wood samples from Nakimu Caves, Glacier National Park, Selkirk Range, British Columbia ( $51^{\circ} 16^{\prime} \mathrm{N}$ Lat, $117^{\circ} 35^{\prime} \mathrm{W}$ Long). Coll. 1965 by D. C. Ford, McMaster Univ., Hamilton.

\section{GSC-538. Nakimu Caves (I)}

$$
270 \pm 140
$$

Wood, at alt ca. $5250 \mathrm{ft}$, exposed in eroding colluvium outside of and below an important abandoned passage in cave system. Colluvium consists of limestone scree from local cliffs mixed with silt washed from higher, till-mantled plateau.

\section{GSC-574. Nakimu Caves (II)}

$4350 \pm 350$

Wood from crack in ceiling of 'Micaschist Passage,' at alt ca. 5020 $\mathrm{ft}, 270 \mathrm{ft}$ below ground surface, 'Micaschist Passage' is 3rd of sequence of 6 underground channels developed by trunk stream to bypass older, larger channel filled with clastic deposits.

General Comment (D.C.F.): date GSC-538 indicates that since tree lived a phase of periglacial accumulation of colluvium has occurred just below treeline. Wood from GSC-574 must have been emplaced close to time that active enlargement of 'Micaschist Passage' ceased. Date corresponds closely to estimate obtained by extrapolating modern mean rate of limestone solution in trunk stream. Sample GSC-574 mixed with dead gas for counting.

\section{Columbia River Flood Plain series, British Columbia}

Samples from test holes drilled in floodplain and delta of Columbia R. S of Revelstoke, British Columbia. Coll. 1966 by R. J. Fulton.

\section{GSC-778. Greenslide, British Columbia (I)}

$6970 \pm 150$

Wood fragments from 105 -ft depth at ferry $2.5 \mathrm{mi} \mathrm{S}$ of Greenslide, E side of Columbia R., $12 \mathrm{mi} \mathrm{S}$ of Revelstoke, British Columbia $\left(50^{\circ}\right.$ $51^{\prime} 20^{\prime \prime} \mathrm{N}$ Lat, $118^{\circ} 06^{\prime} 15^{\prime \prime} \mathrm{W}$ Long). Coll. with split-tube sampler from rotary drill hole (collar alt $1425 \mathrm{ft}$ ) which penetrated $35 \mathrm{ft}$ of gravel overlying $325 \mathrm{ft}$ of medium to fine-grained sand containing pockets of organic detritus. 
GSC-798. Greenslide, British Columbia (II)

Wood from between 190 and $200 \mathrm{ft}$ depth in same rotary drill hole as GSC-778. Sample coll. from cuttings.

GSC-809. Sidmouth, British Columbia (I)

$3480 \pm 130$ 1530 B.C.

Wood and plant detritus from $165 \mathrm{ft}$ depth at Sidmouth, W side of Columbia R., 24 mi S of Revelstoke, British Columbia $\left(50^{\circ} 43^{\prime} 25^{\prime \prime}\right.$ $\mathrm{N}$ Lat, $117^{\circ} 58^{\prime} 10^{\prime \prime} \mathrm{W}$ Long). Coll. with split-tube sampler from rotary drill hole (collar alt $1420 \mathrm{ft}$ ) which penerated $40 \mathrm{ft}$ of pebbly sand overlying $650 \mathrm{ft}$ of medium to fine-grained sand containing scattered pockets of organic detritus.

\section{GSC-819. Sidmouth, British Columbia (II) 1830 B.c.}

Wood fragments from $225 \mathrm{ft}$ depth in same drill hole as GSC-809. Coll. with split-tube sampler.

General Comment (R.J.F.): medium and fine-grained sands are deltaic sediments deposited in Upper Arrow Lake; gravel and pebbly sands are topset and channel materials deposited above finer grained deltaic deposits. Dates indicate Columbia R. delta was extended $12 \mathrm{mi}$ in ca. 3000 to 3500 yr. GSC-778 and GSC-798, similar dates $100 \mathrm{ft}$ apart in Greenslide hole, suggest rapid sedimentation of fine-grained deltaic material. Dates GSC-809 and GSC-819 also are inconclusive. Depending on which way errors are applied, rapid sedimentation or sedimentation as slow as $60 \mathrm{ft}$ in over $700 \mathrm{yr}$ may be indicated. NaOH-leach omitted from pretreatment of GSC-798. GSC-819 mixed with dead gas for counting.

\section{GSC-760. Mt. Breakenridge, British Columbia}

$5950 \pm 140$

Fragments of roots (Abies sp., id by R. J. Mott) from alt $7000 \mathrm{ft}$ (900 ft above tree line) on $\mathrm{W}$ side of Mt. Breakenridge, ca. $60 \mathrm{mi} \mathrm{NE}$ of Vancouver, British Columbia (49 $44^{\prime} \mathrm{N}$ Lat, $121^{\circ} 57^{\prime} \mathrm{W}$ Long). Sample from relatively sheltered site on SE side of nunatak. Coll. 1966 by E. D. Dodson, Falconbridge Nickel Mines, Vanvouver; subm. by J. O. Wheeler. Comment (E.D.D. and J.O.W.): wood exposed by glacier retreat indicates that prior to Neoglacial maximum trees grew at least 900 feet above present tree line. Other dated occurrences of high-level wood exposed by glacial retreat in British Columbia are GSC-169 (3760 \pm 140 , GSC III) from Downie Creek, GSC-197 (5470 \pm 140 , GSC V) from Ruddock Creek, both ca. $200 \mathrm{mi} \mathrm{NE}$, and Y-140 bis $(5260 \pm 200$, Yale V; cf. Y-140, $5850 \pm 180$, Yale II) from Mt. Garibaldi $60 \mathrm{mi} \mathrm{NW}$ of Mt. Breakenridge (cf. also GSC-718, $5250 \pm 130$, wood from Yukon, this list). Date based on one 3-day count.

\section{Jesmond Bog series, British Columbia}

Peat from 2 levels in Borehole $\sharp 2,500 \mathrm{ft}$ from $\mathrm{N}$ edge of Jesmond 
Bog, Jesmond, British Columbia $\left(51^{\circ} 05^{\prime} \mathrm{N}\right.$ Lat, $121^{\circ} 59^{\prime} \mathrm{W}$ Long), at alt ca. $3700 \mathrm{ft}$. Coll. 1965 with Hiller sampler by W. H. Mathews, H. W. Nasmith, G. E. Rouse, and C. Towers; subm. by W. H. Mathews, Univ. of British Columbia, Vancouver.

\section{GSC-511. Jesmond Bog, basal peat}

$9210 \pm 150$ $\mathrm{cm}$; gravel at $670 \mathrm{~cm}$.

\section{GSC-529. Jesmond Bog, upper peat} $(142$ to $160 \mathrm{~cm})$.

General Comment (W.H.M.): GSC-511 gives reasonable minimum age for start of postglacial bog growth at a site close to latest Wisconsin axis of Cordilleran ice sheet in Interior Plateau of British Columbia (Glacial Map of Canada, 1958). GSC-529 gives maximum age for Bridge R. ash (Nasmith et al., 1967) and agrees with limiting dates obtained by Westgate and Dreimanis (1967) of $2120 \pm 150 \mathrm{yr}$ (GSC-577) and 2760 $\pm 140 \mathrm{yr}$ (GSC-531, both in this list). NaOH-leach omitted from pretreatment of both samples.

\section{Quesnel series, British Columbia}

Wood from 3 sites near Quesnel, British Columbia. Coll. 1966 and 1967 by J. E. Armstrong.

\section{GSC-825. Quesnel, British Columbia (I)}

$5790 \pm 140$

Wood from sand bed exposed in 'Big Slide' on E bank Fraser R. ca. $10 \mathrm{mi} \mathrm{N}$ of Quesnel (53 $53^{\circ} 05^{\prime} \mathrm{N}$ Lat, $122^{\circ} 31^{\prime} \mathrm{W}$ Long). Sand bed overlies slide deposit resting on late Tertiary sediments and underlies fine sand and silt, and a till-like deposit. All form part of Fraser R. terrace at ca. $200 \mathrm{ft}$ above river; post-Tertiary deposits are ca. $100 \mathrm{ft}$ thick. Comment (J.E.A.): date indicates that all deposits above late Tertiary sediments were laid down in postglacial time and till-like material overlying sand bed is redeposited. Fraser $\mathbf{R}$. has incised more than $200 \mathrm{ft}$ since deposition of wood-bearing sand. Date based on one 3-day count.

\section{GSC-853. Quesnel, British Columbia (II)}

$6640 \pm 140$

Wood from bed of sand exposed along $S$ bank Cottonwood R. ca.

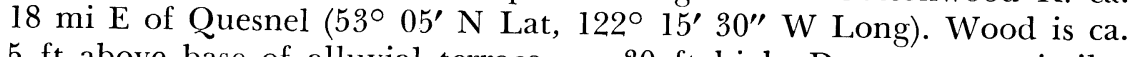
$5 \mathrm{ft}$ above base of alluvial terrace, ca. $30 \mathrm{ft}$ high. Downstream, similar deposits overlie till. Comment (J.E.A.): date indicates sediments are postglacial; and, with GSC-825 (5790 \pm 140 , this series) shows period of aggradation along rivers lasted at least ca. $850 \mathrm{yr}$. Both rivers are now degrading. Date based on one 3-day count. 
GSC-851. Quesnel, British Columbia (III)

Wood from till overlying late Tertiary sediments, containing organic material, on E bank Fraser R. ca 1 mi $\mathrm{N}$ of Quesnel $\left(53^{\circ} 00^{\prime} \mathrm{N}\right.$ Lat, 122 $31^{\prime}$ W Long). Wood is spruce or larch; associated pollen appear to be mainly late Tertiary species. Comment (J.E.A.): date suggests wood possibly derived from underlying late Tertiary sediments, although similar pieces of wood were not found in Tertiary deposits near site. Nature of pollen suggests similar source. Date based on one 1-day count.

\section{GSC-852. North Vancouver, British Columbia}

$960 \pm 130$

\section{A.D. 990}

Shells, mainly large pectens (Solen sicarius), coll. from marine clay during excavation for new dock on $\mathrm{N}$ side Burrard Inlet in North Vancouver, British Columbia $\left(49^{\circ} 18^{\prime} \mathrm{N}\right.$ Lat, $123^{\circ} 05^{\prime} \mathrm{W}$ Long), at alt -30 $\mathrm{ft}$. Recent distribution of this species is from Vancouver Island to Baja California on sandy mud flats and at max. depth $150 \mathrm{ft}$. Coll. 1966 by W. Barker and S. Wooster; subm. by J. E. Armstrong. Comment (J.E.A.): date confirms assumption, based on presence of large pectens, that shellbearing marine clay is of recent origin. Pretreatment involved leaching of outermost $50 \%$ of shell. Date based on one 3-day count.

\section{Northern Canada, Mainland}

\section{GSC-718. Kletsan Creek, Yukon}

$5250 \pm 130$

3300 B.c.

Wood from fresh exposure on SE bank, W tributary of Kletsan Creek, Yukon Territory (61 $31^{\prime} \mathrm{N}$ Lat, $140^{\circ} 58^{\prime} \mathrm{W}$ Long), from $2 \mathrm{ft}$ below top of unoxidized gravel overlying oxidized(?) till and underlying pebbly silt, volcanic ash, and turf. Coll. 1966 by V. Rampton. Comment (V.R.): relationship of gravel to climatic and glacial history of region is presently unclear; however, site is ca. $200 \mathrm{ft}$ above tree line, suggesting conditions formerly more favorable to tree growth (cf. GSC-760, $5950 \pm 140$, this list, for comments on trees above tree line in $\mathrm{S}$ British Columbia). Date based on one 3-day count.

GSC-524. Stewart River, Yukon (II)

Wood from volcanic ash, S side Stewart R., Yukon Territory $\left(63^{\circ}\right.$ $30.2^{\prime} \mathrm{N}$ Lat, $137^{\circ} 16^{\prime} \mathrm{W}$ Long). Sample from gully $1300 \mathrm{ft}$ downstream of discontinuous exposure. Ash layer 1 to 5 in. thick lies in surface layer of organic silt and peat, overlying gravel, till, and gravel. Coll. 1965 by O. L. Hughes. Comment (O.L.H.): upper gravel and till are products of Reid advance (Bostock, 1966); hence date is minimum for that event. Wood from similar ash exposed $43 \mathrm{mi}$ downstream is $>38,940 \mathrm{yr}$ old (GSC-342, GSC V). Date based on one 3-day count.

\section{GSC-565. McQuesten River, Yukon}

$1590 \pm 150$

Charcoal from top of buried soil in $\mathrm{N}$ bank McQuesten R., $0.5 \mathrm{mi} \mathrm{W}$ of Vancouver Creek, Yukon Territory, (63 $38^{\prime}$ N Lat, $137^{\circ} 06^{\prime} \mathrm{W}$ Long). 
Soil is developed in fine sand overlying gravel, sand, and silt, and is overlain by loess with 2 weak soils. Coll. 1965 by O. L. Hughes. Comment (O.L.H.): charcoal probably resulted from forest fire; similar loess is presently being deposited at top of bank. NaOH-leach omitted from sample pretreatment. Sample mixed with dead gas for counting.

\section{GSC-472. Gravel Lake, Yukon}

$10,930 \pm 190$

Gyttja from base of $3 \mathrm{~m}$-thick organic layer, SE end Gravel Lake, Yukon Territory (630 48.5' $\mathrm{N}$ Lat, $137^{\circ}$ 53.5' W Long). Water depth $1.5 \mathrm{~m}$. Coll. 1965 with Hiller peat sampler by O. L. Hughes. Comment (O.L.H.): Gravel Lake lies in Tintina Trench on thick drift fill presumed older than deposits of Reid advance and hence $>42,900 \mathrm{yr}$ old (GSC-524, this list). Lake is impounded on NE side by large fan and at its NW (outlet) end by extensive bog; hence lake may be much younger than underlying drift. NaOH-leach omitted from sample pretreatment. Sample mixed with dead gas for counting.

\section{GSC-527. Hunker Creek, Yukon}

Spruce wood from Fant and Norbeck placer pit, at limit of Hunker Creek between Too Much Gold and Gold Bottom Creeks, Klondike District, Yukon Territory (63 $58^{\prime} \mathrm{N}$ Lat, $138^{\circ} 57^{\prime} \mathrm{W}$ Long). Taken from organic silt overlying auriferous gravel and overlain, successively, by silty gravel with mammoth, horse, and bison remains, organic silt, and peat. Area has not been glaciated. Coll. 1960 by O. L. Hughes. Comment (O.L.H.): date is based on one 4-day count in 5-L counter at 4 atm and supercedes earlier date of $>35,000$ (I(GSC)-181, Isotopes II) on same sample.

\section{White River ash series, Yukon}

Ash derived from source near Yukon-Alaska Boundary, $10 \mathrm{mi} \mathrm{S}$ of White R., distributed in E Alaska and south-central Yukon Territory as 2 lobes, 1 extending northward, 1 eastward (Bostock, 1952). Fernald (1962) reported ages of $1520 \pm 100$ (I-176, peat above ash) and $1750 \pm$ 110 (I-275, peat below ash) from samples from upper Tanana Valley, Alaska, from which Stuiver et al. (1964) calculated an age of $1635 \pm$ $80 \mathrm{yr}$ for ash of $\mathrm{N}$ lobe. They reported ages of $1460 \pm 70 \mathrm{yr}$ (Y-1363, peat above ash) and $1390 \pm 70$ (Y-1390, peat below ash) from near Kaskawulsh Glacier, Yukon Territory; they calculated age of $1425 \pm 50 \mathrm{yr}$ for ash of $\mathrm{E}$ lobe, and suggested 2 lobes possibly represent separate eruptions of ash $200 \mathrm{yr}$ apart.

GSC-400. Yukon River, Yukon

$1990 \pm 130$

40 B.C.

Wood from silt immediately beneath 2-in-thick ash, E bank Yukon R., $1.3 \mathrm{mi}$ above mouth of Coal Creek (64. $28^{\prime} \mathrm{N}$ Lat, $140^{\circ} 27.5^{\prime} \mathrm{W}$ Long). Ash is $2.5 \mathrm{ft}$ below flood plain surface $4 \mathrm{ft}$ above high water level of Yukon R. Coll. 1961 by O. L. Hughes. 
GSC-408. Finlayson Lake map-area, Yukon

Peat from immediately beneath 2-in-thick ash layer, 14 in. below surface of string bog between Black and North R., (61 $01^{\circ} \mathrm{N}$ Lat, $130^{\circ}$ 25' W Long). Coll. 1959 by L. H. Green.

\section{GSC-343. 'Glacier Creek,' Yukon}

$1240 \pm 130$

A.D. 710

Peat from $1 \mathrm{~cm}$ below to $1 \mathrm{~cm}$ above ash layer 1 to $2 \mathrm{~mm}$ thick at depth $0.7 \mathrm{~m}$ in bog on $\mathrm{W}$ side North Klondike R. $\left(64^{\circ} 08.6^{\prime} \mathrm{N}\right.$ Lat, $138^{\circ} 32.5^{\prime} \mathrm{W}$ Long). Bog lies between river and Dempster Highway 1.5 mi S of crossing of 'Glacier Creek.' Coll. 1964 by O. L. Hughes.

General Comment (O.L.H.): age of GSC-400 is compatible with its position beneath ash of N lobe. GSC-408 lies beneath ash of $\mathrm{E}$ lobe, and GSC-343 lies between 2 lobes as delineated by Bostock (1952), yet dates are some $200 \mathrm{yr}$ younger than age of $\mathrm{E}$ lobe as reported by Stuiver et al. (1964). Ash blanket within E lobe is remarkably continuous single layer; it is unlikely that these localities represent a separate, hitherto unsuspected ash fall. No explanation for discrepancy is available. Each of 3 dates based on one 3-day count.

\section{North Fork Pass series, Ogilvie Mountains, Yukon}

During last advance of valley glaciers in Ogilvie Mts., Yukon Territory, ice advanced out of headwaters of East Blackstone R. into $\mathrm{N}$ continuation of North Fork Pass, where it diverged $\mathrm{N}$ and $\mathrm{S}$ to form a "hammer-head"-shaped moraine, S loop of which now forms divide in North Fork Pass (Vernon and Hughes, 1966, p. 12). Samples coll. 1965 within limits of moraine system by $\mathrm{O}$. L. Hughes. Borings were made with SIPRE-type ice-corer (cf. Hughes and Terasmae, 1963).

\section{GSC-411. East Blackstone River, Yukon}

$5070 \pm 130$

3120 B.c.

Organic silt from E bank East Blackstone R., ca. 0.5 mi upstream from crossing of Dempster Hwy and river $\left(64^{\circ} 35.7^{\prime} \mathrm{N}\right.$ Lat, $138^{\circ} 20^{\prime}$ W Long). Sample coll. at downstream end of exposure near base of 10 $\mathrm{ft}$ sec. of fluvial sediments, mainly gravel, with peat and organic silt, disconformably overlying glaciolacustrine(?) silt.

GSC-416. Dempster Highway, Yukon (I)

$$
3100 \pm 130
$$

Basal peat from 4.6 to $4.75 \mathrm{ft}$ depth in boring at margin of small pond, at $\mathrm{N}$ fringe of moraine, $\mathrm{W}$ side Dempster Hwy at Mile $55.8\left(64^{\circ}\right.$ $36^{\prime} \mathrm{N}$ Lat, $138^{\circ} 22.5^{\prime} \mathrm{W}$ Long). Peat underlain by till(?).

\section{GSC-469. Dempster Highway, Yukon (II)}

$3180 \pm 130$

1230 B.C.

Basal peat from 4.15 to $4.3 \mathrm{ft}$ depth in boring, $16 \mathrm{ft}$ E of GSC-416, small pond, W side Dempster Hwy at Mile 55.8 (64. $36^{\prime} \mathrm{N}$ Lat, $138^{\circ}$ 22.5' W Long). Peat underlain by till(?) or coarse outwash(?). 
GSC-470. North Fork Pass, Yukon (I)

$11,250 \pm 160$

\section{B.C.}

peat hummic silt with twigs (dwarf birch?) from $16 \mathrm{ft}$ depth in boring in peat hummock, NE side of large pond in flat $\mathrm{N}$ of moraine loop forming divide in North Fork Pass (64 $35^{\prime} \mathrm{N}$ Lat, $138^{\circ} 17.5^{\prime} \mathrm{W}$ Long); 6 $\mathrm{ft}$ fibrous peat overlies $10+\mathrm{ft}$ silty sand, grit, and pebbles with sparse organic material.

GSC-471. North Fork Pass, Yukon (II)

$7050 \pm 140$

5100 B.C.

Organic silt with twigs (dwarf birch?) from 6.6 to $6.8 \mathrm{ft}$ depth in boring in peat hummock $200 \mathrm{ft} \mathrm{NW}$ of GSC-470 $\left(64^{\circ} 35^{\prime} \mathrm{N}\right.$ Lat, $138^{\circ}$ $17.5^{\prime}$ W Long); $4 \mathrm{ft}$ fibrous peat overlies $2.8+\mathrm{ft}$ of silt with grit.

General Comment (O.L.H.): minimum age of moraine in North Fork Pass, previously $7510 \pm 100$ yr (GSC-50, GSC I), extended by GSC-470 to $11,250 \pm 160$. Date may be older than beginning of loess deposition $10,900 \pm 150$ yr ago (GSC-311, GSC V) in bog sequence near Chapman Lake, $16 \mathrm{mi} \mathrm{N}$ of moraine system, assumed to correlate with last glacial advance. If age difference is real (i.e., not within limits of error of dating method) and if silt deposition was related to glacial advance, difference may be due to one or both of 2 factors: 1) change of East Blackstone $\mathrm{R}$. from normal to braided stream that was source of loess, may have taken place during retreat following advance; 2) time lag may have occurred between change in stream regimen near ice margin and response of stream to change downstream. Pretreatment of GSC-411 included cold NaOH-leach. Dates for GSC-411 and GSC-470 each based on one 3-day count.

\section{East Blackstone River series, Yukon}

Peat and organic silt from boreholes in permanently frozen bog bordering small pond, in moraine where unnamed valley opens from $\mathrm{W}$ into valley of East Blackstone R., Yukon Territory (64. $38^{\prime} \mathrm{N}$ Lat, $138^{\circ} 24^{\prime}$ W Long). Coll. 1965 with SIPRE-type ice-corer by O.L. Hughes.

GSC-415. East Blackstone River, peat

Peat from 5.3 to $5.5 \mathrm{ft}$ depth in boring on $\mathrm{W}$ side of pond.

$$
4890 \text { в.c. }
$$

\section{$13,740 \pm 190$ \\ East Blackstone River, organic silt 11,790 B.c.} General Comment (O.L.H.): date GSC-515 is minimum side of pond. ment of vegetation on morate GS-515 is minimum for establishsystem in North Fork Pass (Vernon and Hughes, 1966) that ith moraine $11,250 \pm 160 \mathrm{yr}$ old (GSC-470, this list); moraine may correlate more closely with older moraine system near Chapman Lake, ca. $16 \mathrm{mi} \mathrm{N}$, older than 13,870 $\pm 180 \mathrm{yr}$ (GSC-296, GSC V). NaOH-leach omitted from pretreatment of GSC-515. Date GSC-415 based on one 4-day count. 


\section{GSC-409. Blackstone River, Yukon (II)}

Organic silt from $8.7 \mathrm{ft}$ depth in boring made with SIPRE-type ice-corer on SW edge of small pond, W of Blackstone R. and $5.2 \mathrm{mi} \mathrm{N}$ of Chapman Lake, Yukon Territory (64. $56^{\prime} \mathrm{N}$ Lat, $138^{\circ} 20^{\prime} \mathrm{W}$ Long). Pond is in subdued moraine beyond limit of and higher than moraine of "intermediate" age (older than 13,870 \pm 180, GSC-296, GSC V) in vicinity of Chapman Lake. Coll. 1964 by O. L. Hughes. Comment (O.L.H.): sample from depth $11.4 \mathrm{ft}$ in same boring (GSC-295, $6650 \pm$ 140, GSC V) was younger than expected; this sample, dated as check, is consistent with GSC-295. Organic accumulation at locality began long after construction of moraine. NaOH-leach omitted from sample pretreatment.

\section{GSC-586. Snake River, Yukon (II)}

$9750 \pm 150$

Silty peat from base of $10-\mathrm{ft}$ sec. of alluvial silt, overlying successively gravel, organic silt with wood, boulder gravel, and bedrock of a terrace on W side of Snake R., Yukon Territory $\left(65^{\circ} 41^{\prime} \mathrm{N}\right.$ Lat, $133^{\circ}$ $26^{\prime}$ W Long). Coll. 1962 by O. L. Hughes. Comment (O.L.H..): wood from beneath gravel is $>31,000$ yr old (GSC-181, GSC IV). Gravel interpreted as outwash of late-Wisconsin valley glaciation in upper Snake R. Outwash deposition ceased prior to 9750 B.P.; river was incised ca. $225 \mathrm{ft}$ after that date. $\mathrm{NaOH}$-leach omitted from sample pretreatment.

\section{GSC-785. Gordon Bay, Northwest Territories}

$$
\mathbf{2 2 8 0} \pm \mathbf{1 5 0}
$$

A.D. 330

Fragments of whole shells of marine pelecypods, mainly Portlandia arctica and Macoma calcarea (id. by F. J. E. Wagner), from exposure at head of Gordon Bay, Bathurst Inlet, Northwest Territories $\left(66^{\circ}\right.$ $49.5^{\prime} \mathrm{N}$ Lat, $107^{\circ} 05^{\prime} \mathrm{W}$ Long), at alt 4 to $5 \mathrm{ft}$, within basal silt-clay unit with scattered plant detritus. Coll. 1962 by W. Blake, Jr. Comment (W.B., Jr.,): date is surprisingly young, in view of dates $2170 \pm 140$ (GSC-138) and $1850 \pm 140$ (GSC-137, both in GSC III) on plant detritus at alt $19 \mathrm{ft}$ and shells at alt $24 \mathrm{ft}$ in sec. Possibly thin shells were contaminated, and small sample $(5.5 \mathrm{~g})$ allowed no sample pretreatment to remove outer shell layers. Sample mixed with dead gas for counting. Date based on one 4-day count.

\section{GSC-737. Hope Bay, Northwest Territories}

$8720 \pm 150$

\section{0 в.c.}

Whole shells and fragments of marine pelecypods Hiatella arctica and Mya truncata from surface of sand-silt deposit $3.5 \mathrm{mi}$ W of Hope Bay, S side Melville Sound, Northwest Territories $\left(68^{\circ} 06.5^{\prime} \mathrm{N}\right.$ Lat, $106^{\circ}$ 54' W Long), at alt ca. $470 \mathrm{ft}$. Coll. 1962 by H. H. Bostock for W. Blake, Jr. Comment (W.B., Jr.): shells are older than other shells at similar alt near Bathurst Inlet (cf. GSC-344, $8360 \pm 150$, alt $480 \mathrm{ft}$; GSC-594, 8220 \pm 160 , alt $480 \mathrm{ft}$; GSC-604, $8070 \pm 160$, alt $500 \mathrm{ft}$; GSC-636, $8230 \pm$ 
140, alt $490 \mathrm{ft}$; all listed in GSC VI), indicating relative sea level 8700 yr ago was above alt of coll. site. Date based on one 3-day count.

\section{GSC-110-2. MacAlpine Lake, Northwest Territories}

$8090 \pm 160$

Whole shells and fragments of marine pelecypod Hiatella arctica from ground surface down to 1 -ft depth in silt, alt ca. $600 \mathrm{ft} .18 \mathrm{mi} \mathrm{NW}$ of MacAlpine Lake, Northwest Territories $\left(66^{\circ} 49^{\prime} \mathrm{N}\right.$ Lat, $103^{\circ} 28^{\prime} \mathrm{W}$ Long). Coll. 1962 by W. Blake, Jr. Comment (W.B., Jr.): re-dating done as sample is critical for age of MacAlpine Lake Moraine. Date agrees closely with original date $8160 \pm 140$ (GSC-110, GSC III; Blake 1963, 1966), on which pretreatment included leaching of outer $10 \%$ of shell. For GSC-110-2 pretreatment involved leaching of outer $50 \%$ of shell. Date based on one 3-day count.

Marine pelecypod shell fragments (Mytilus edulis) from fine sand in river bank, cut into probable deltaic terrace, alt $160 \mathrm{ft}, \mathrm{S}$ side Back R., $8 \mathrm{mi} \mathrm{SW}$ of mouth of Hermann R., Northwest Territories $\left(66^{\circ} 08^{\prime}\right.$ N Lat, $96^{\circ} 18^{\prime} \mathrm{W}$ Long). Coll. 1966 by B. G. Craig. Comment (B.G.C.): date, on sample ca. $340 \mathrm{ft}$ below marine limit (Craig, 1961) may give age of relative stand of sea at $160 \mathrm{ft}$. Date is minimum for withdrawal of ice to SE from MacAlpine Lake end moraine (Blake, 1963; Craig, 1965) and agrees closely with date on marine shells (I-1224, $6015 \pm 150$, GSC V; Blake, 1966) from Beverly Lake, Thelon R. Valley.

\section{GSC-725. Baker Lake ( $21 \mathrm{ft})$ shells}

$5220 \pm 140$

3270 B.c.

Marine pelecypod shells (Hiatella arctica) from ground surface and up to 18 in. depth in sandy gravel, alt $21 \mathrm{ft}$, Baker Lake settlement, Northwest Territories (64 ${ }^{\circ} 19^{\prime} \mathrm{N}$ Lat, $96^{\circ} 03^{\prime} \mathrm{W}$ Long). Coll. 1966 by J. G. Fyles and B. G. Craig. Comment (B.G.C. and J.G.F.): shells form part of Thelon Shell series (GSC V) and were assumed to have been deposited near sea level. Other samples of similar age in series are considerably higher (e.g., GSC-299, $5480 \pm 150$, alt $295 \mathrm{ft}$, GSC V); age of tundra-plant debris from similar alt assumed to date stand of sea at 25 to $30 \mathrm{ft}$ (GSC-23, $1800 \pm 60$, GSC I) is considerably younger, indicating this sample was either deposited in deep water or was reworked from higher alt. Date based on one 3-day count.

\section{GSC-691. Hall Beach, Northwest Territories}

Articulated marine pelecypod shells (Mya truncata) at 3-ft depth in stony silt in sec., ca. $0.25 \mathrm{mi} \mathrm{E}$ of airstrip at Hall Beach, Melville Peninsula, Northwest Territories (68 $48^{\circ} \mathrm{N}$ Lat, $81^{\circ} 14^{\prime} \mathrm{W}$ Long), at alt ca. 23 ft. Coll. 1966 by J. T. Andrews, Geog. Branch, Ottawa, for B. G. Craig. Comment (J.T.A. and B.G.C.): date indicates average rate of uplift for last $1000 \mathrm{yr}$ in this area is ca. $2 \mathrm{ft} / 100 \mathrm{yr}$ (cf. Andrews, 1966). 


\section{Gilmour Island series, Ottawa Islands, Northwest Territories}

Marine shells from Gilmour Island, Ottawa Islands, Northwest Territories $\left(59^{\circ} 50^{\prime} \mathrm{N}\right.$ Lat, $80^{\circ} 00^{\prime} \mathrm{W}$ Long), ca. $68 \mathrm{mi} \mathrm{W}$ of $\mathrm{E}$ coast of Hudson Bay. Coll. 1966 by J. T. Andrews and G. Falconer, Geog. Branch, Ottawa.

GSC-688. Gilmour Island, $485 \mathrm{ft}$

Whole shells and fragments, some weathered, of Mya truncata, Hiatella arctica, and Balanus sp. on and in beach gravel at alt $485 \mathrm{ft}$, ca. 16 to $23 \mathrm{ft}$ below local marine limit.

GSC-706. Gilmour Island, $455 \mathrm{ft}$

$7430 \pm 180$

Marine pelecypod shells (Hiatella arctica, Mya truncata, and Macoma sp.) from surface of delta at alt $455 \mathrm{ft}$, less than $2 \mathrm{mi}$ W of GSC-688. Local marine limit at ca. $510 \mathrm{ft}$. Shells polished, presumably from sand blast.

General Comment (J.T.A. and G.F.): date GSC-688 was unexpectedly young compared with dates from Churchill, Manitoba (GSC-92, $7270 \pm$ 120, GSC III) and from S of James Bay (I (GSC)-14, $7875 \pm 200$, Isotopes I; Gro-1698, $7280 \pm 80$, Terasmae and Hughes, 1960; I-1256, $7523 \pm$ 200, Blake, 1966); younger date for higher sample might be due to contamination, as this sample was larger but much more fragmented than GSC-706. Partly from rebound curve calculated from lower sites, GSC-706 is assumed a closer approximation to time of deglaciation, although still younger than expected. Dates suggest late deglaciation of Ottawa Islands. Sample GSC-706 mixed with dead gas for counting; date based on one 3-day count.

\section{Sugluk Inlet series, Quebec}

Shells and organic debris from marine sediments near Sugluk Inlet, Quebec. Coll. 1962 and 1965 by B. Matthews, McGill Univ., Montreal; subm. by W. Blake, Jr.

\section{GSC-672. Sugluk Inlet, shells}

$7970 \pm 250$

Shell fragments of Hiatella arctica in silty-clay at alt $324 \mathrm{ft}$ in 'Rivière Sugluk' valley near Sugluk village $\left(62^{\circ} 12^{\prime} \mathrm{N}\right.$ Lat, $75^{\circ} 38^{\prime} \mathrm{W}$ Long). Sample coll. from mud boils (near distal side of breached end moraine) from highest fossiliferous marine deposits on SE side of Sugluk Inlet, near local marine limit (alt ca. $340 \mathrm{ft}$ ). Comment (B.M.): result compares favorably with I-729 $(7650 \pm 250$, Matthews, 1966) from near marine limit on NW side of Sugluk Inlet. Date gives minimum age for nearby end moraine and general deglaciation of $\mathrm{S}$ shore of Hudson Strait. Few species present (only Mya truncata and Balanus sp. besides $H$. arctica) compared with low-level deposits (>50 spp.; cf. Matthews, 1967) suggest rigorous marine conditions ca. 8000 yr ago. Sample mixed with dead gas for counting. Date based on one 4-day count. 
GSC-812. Sugluk Inlet, organic debris (I)

$4770 \pm 140$

2820 B.C.

mosses, ericaceous remains, Salix twigs and leaves from 1.5 in.-thick peat in marine shelly sand with thin organic (salt marsh) layers. Sample from alt $78 \mathrm{ft}$ (14 ft below surface of marine terrace) from river-bank exposure near Sugluk village $\left(62^{\circ} 13^{\prime} \mathrm{N} \mathrm{Lat,} 75^{\circ}\right.$ 38' W Long). Comment (B.M.): date gives minimum age of "Upper Tunit Beach" (100 ft alt). Shells from raised beach at similar alt at Kugluk Cove are $6070 \pm 140$ (N-285, RIKEN III; Matthews, 1967), giving maximum age of "Upper Tunit Beach." GSC-812 probably more closely approximates time of beach formation than does $\mathrm{N}-285$. Thin peaty layers (containing fossil mosses, with rhizoids, in living position) interbedded with fossiliferous marine material in both "Upper Tunit Beach" and "Hemithyris Beach" (see GSC-818, this series) suggest beaches were formed during marine transgression(s). Sample mixed with dead gas for counting. Date based on one 3-day count.

\section{GSC-818. Sugluk Inlet, organic debris (II)}

$2840 \pm 160$ mine marine silty sand and thin peaty layers, near Sugluk village $\left(62^{\circ} 13^{\prime} \mathrm{N}\right.$ Lat, $75^{\circ} 39^{\prime} \mathrm{W}$ Long). Sample coll. from cut-bank exposure in lowest well-formed marine terrace (alt 15-20 ft) in N Ungava. Comment (B.M.): date gives age of "Hemithyris Beach" (alt $20 \mathrm{ft}$ ) and suggests uplift in Sugluk Inlet in last $3000 \mathrm{yr}$ may have been less than 6 in./100 yr. Date presumed closer to correct age of beach than N-282 (5220 \pm 130 , RIKEN III), date on shells at $20 \mathrm{ft}$, Sugluk Inlet; also see GSC-537 (1600 士 140, GSC VI), date on detrital peat at alt $28 \mathrm{ft}$, Sugluk Inlet, Pollen studies by D. D. Bartley (Botany Dept., Leeds Univ.) indicate high values of long distance types in sample; i.e., conifer pollen forms $45.5 \%$ of total pollen excluding spores. Either climate was warmer $2800 \mathrm{yr}$ ago, resulting in northward shift of forest-tundra boundary, or Pinus and Picea are over-represented because of decrease in pollen rain from local species of plants. Presence of mollusc Periploma papyratium in marine silt below dated peat may indicate slightly higher sea temperature 2800 yr ago than at present. Sample mixed with dead gas for counting.

\section{GSC-801. Deception Bay, Quebec}

$6080 \pm 160$

Shells of Mya truncata from 1-ft-thick layer of shelly gravel with organic debris, alt $180 \mathrm{ft}$, in gravel pit in marine terrace remnant, SW side Deception Bay, Quebec (62 $08^{\prime} \mathrm{N}$ Lat, $74^{\circ} 41^{\prime} \mathrm{W}$ Long). Gravel overlies fossiliferous silt and is overlain by solifluction material and beach shingle. Coll. 1965 by B. Matthews; subm. by W. Blake, Jr. Comment (B.M.): date gives approx. age of "Axinopsida Beach" (180 ft alt), traceable along coast of $\mathrm{N}$ Ungava. Abundant plant remains and 
intertidal and shallow water molluscs (i.e., Littorina saxatilis, Acmaea testudinalis, Axinopsida orbiculata, and Mytilus edulis) in beach deposit suggest slightly better climate and sea-ice conditions when beach formed than at present. Date based on one 3-day count.

\section{GSC-697. Tasisuak Lake, Labrador \\ $4060 \pm 130$ \\ 2110 B.c.}

Marine pelecypod shells (Mya truncata, Mya arenaria, Clinocardium ciliatum, Hiatella arctica, Serripes groenlandicum, Chlamys islandicus; id. by K. V. W. Palmer, Paleontological Res. Inst., Ithaca, New York) from S shore of Tasisuak Lake, Labrador (56 $37^{\prime} 49^{\prime \prime} \mathrm{N}$ Lat, $62^{\circ} 33^{\prime} 55^{\prime \prime}$ W Long), at alt ca. $10 \mathrm{ft}$. Coll. 1962 by E. P. Wheeler II, Cornell Univ., Ithaca, New York; subm. by J. T. Andrews. Comment (E.P.W.): shell fragments occurred in silt but most shells were concentrated by waveaction on beach, which implies relative sealevel was considerably above present to allow suitable conditions of salinity in narrow fiord valley where silt was being deposited. Coarse deltaic deposits rise ca. $20 \mathrm{ft}$ above lake; date is minimum for relative sealevel at alt $30 \mathrm{ft}$. Date based on one 4-day count.

\section{Northern Canada, Arctic Archipelago}

\section{GSC-708. Barrier Inlet, Baffin Island (solifluction)}

$1790 \pm 130$

A.D. 160

Black organic debris overlying sand and underlying solifluction debris, ca. $5 \mathrm{mi} \mathrm{N}$ of head of Barrier Inlet, Baffin Island Northwest Territories $\left(62^{\circ} 34^{\prime} \mathrm{N}\right.$ Lat, $68^{\circ} 52^{\prime} \mathrm{W}$ Long), at estimated alt ca. $125 \mathrm{ft}$. Coll. 1965 by W. Blake, Jr. Comment (W.B., Jr.): solifluction debris overrode vegetation earlier at this site than at site near Lake Harbour (GSC$591,680 \pm 180$, GSC VI). Date is minimum for emergence. NaOH-leach omitted from sample pretreatment.

\section{GSC-827. 'Iqaluaaluit' Fiord, Baffin Island}

$6650 \pm 180$

Marine pelecypod shells (Mya truncata, Portlandia arctica) sparsely distributed on surface of silty clay at outlet of unnamed lake, $1 \mathrm{mi} S$ of middle part of 'Iqaluaaluit' Fiord, Baffin Island, Northwest Territories (68 $32^{\prime} \mathrm{N}$ Lat, $68^{\circ} 26.5^{\prime} \mathrm{W}$ Long), at alt ca. $130 \mathrm{ft}$. Coll. 1966 by P. Lewis for J. T. Andrews. Comment (J.T.A.): date may refer either to maximum marine submergence at alt ca. $185 \mathrm{ft}$ or to readvance during which ice-contact deltaic sands at alt ca. $160 \mathrm{ft}$ were deposited. Both events may have occurred within limits of error of date, i.e., between 6830 and 6470 yr B.P. Because of small sample $(6.0 \mathrm{~g})$, only outer $10 \%$ removed before dating. Sample mixed with dead gas for counting. Date based on one 4-day count.

\section{Ekalugad Fiord series, Baffin Island}

Marine pelecypod shells from 2 localities along $S$ side of Ekalugad Fiord, Baffin Island, Northwest Territories. 
GSC-707. 'Qammattalik'

$9180 \pm 1140$

7230 B.C.

Shells, mainly Portlandia arctica but also Mya truncata and Clinocardium ciliatum, from within and surface of massive clay deposits 0.5 mi SE of 'Qammattalik' ("Fox-Charlie Bay"), Baffin Island (68 $42.8^{\circ}$ $\mathrm{N}$ Lat, $68^{\circ} 39^{\prime} \mathrm{W}$ Long), at alt ca. $180 \mathrm{ft}$. Local marine limit at alt ca. 235 ft. Coll. 1966 by J. T. Andrews and J. T. Buckley, Geog. Branch, Ottawa.

\section{GSC-739. 'Kanguursit'}

$$
6930 \pm 150
$$

Shells, mainly Mya truncata and Portlandia arctica, but also Serripes groenlandicus and Clinocardium ciliatum scattered sparsely within blueblack clay $0.3 \mathrm{mi} \mathrm{SE}$ of 'Kanguursit' and ca. $1.5 \mathrm{mi} \mathrm{E}$ of mouth of 'South Ekalugad R.,' Baffin Island ( $68^{\circ} 44^{\prime} \mathrm{N}$ Lat, $68^{\circ} 56^{\prime} \mathrm{W}$ Long), at alt. ca. $110 \mathrm{ft}$. Local marine limit at alt ca. $130 \mathrm{ft}$. Clay overlain by deltaic shallow-water deposits. Coll. 1966 by J. T. Buckley.

General Comment (J.T.A. and J.T.B.): moraines E of 'Qammattalik' deposited during readvance phase following deposition of clay from which shells for GSC-707 were coll. Moraines relating to readvance are traceable for $>100 \mathrm{mi}$ in Ekalugad Fiord-Kangok Fiord area. Best age estimate of this phase, bracketed by other radiocarbon dates (Andrews, 1967 ) is ca. 7900 yr в.P., i.e., close to lower confidence limit on GSC-707, 8040 yr в.P. GSC-739 postdates readvance. Both samples were small with thin shells. Date for GSC-707 (7.1 g sample) based on one 4-day count. For GSC-739 (10.6 g) only outer $5 \%$ of shell removed before dating; date based on one 5-day count. Both samples mixed with dead gas for counting.

\section{GSC-813. Pitchford Fiord, Baffin Island}

$8630 \pm 190$

Whole shells and fragments of marine pelecypod, Hiatella arctica, from bedded fine sand and silt $0.75 \mathrm{mi} \mathrm{S}$ of head of Pitchforth Fiord, Baffin Island, Northwest Territories (68 $57.5^{\prime} \mathrm{N}$ Lat, $68^{\circ} 34^{\prime} \mathrm{W}$ Long). Beds containing shells traced to surface at alt $180 \mathrm{ft}$; local marine limit at alt ca. $225 \mathrm{ft}$. Coll. 1966 by J. T. Andrews. Comment (J.T.A.): date is minimum deglaciation of innermost part of Pitchforth Fiord. No sample pretreatment as only $5.6 \mathrm{~g} \mathrm{subm}$. Sample mixed with dead gas for counting. Date based on one 4-day count.

\section{GSC-814. Dewar Lakes, Baffin Island}

$610 \pm 160$

Organic material at $2 \mathrm{ft}$ depth in frozen ground (July 23rd) ca. 12 mi NW of Dewar Lakes DEW-Line Site, Baffin Island, Northwest Territories ( $68^{\circ} 47^{\prime} \mathrm{N}$ Lat, $71^{\circ} 31^{\prime} \mathrm{W}$ Long), at alt ca. $1850 \mathrm{ft}$. Sample probably not lowest organic material in sec. Coll. 1966 by D. M. Barnett, Geog. Branch, Ottawa. Comment (D.M.B.): date is minimum for deglaciation but is younger than I-2414 (1360 \pm 105; Andrews, 1967), 
basal organic debris from section $8 \mathrm{mi}$ E. A moraine occurs between the 2 sites. Sample mixed with dead gas for counting.

\section{Clyde Inlet series, Baffin Island}

Samples from distinct delta levels at head of Clyde Inlet, Baffin Island, Northwest Territories $\left(69^{\circ} 51^{\prime} \mathrm{N}\right.$ Lat, $70^{\circ} 29^{\prime} \mathrm{W}$ Long). Coll. 1965 by D. M. Barnett.

\section{GSC-583. Clyde Inlet, 16 ft shells}

Whole marine pelecypod shells (Hiatella arctica and Mya truncata) at alt $16 \mathrm{ft}$ in foreset beds of prominent low-level delta (alt ca. $20 \mathrm{ft}$ ).

\section{GSC-584. Clyde Inlet, $16 \mathrm{ft}$ plant debris}

$3450 \pm 170$

Plant debris at alt $16 \mathrm{ft}$ in foreset beds of prominent low-level delta (alt ca. $20 \mathrm{ft}$ ). Debris is stratigraphically below shells (GSC-583) though from adjacent stratum.

\section{GSC-631. Clyde Inlet, 95 ft shells}

$6220 \pm 140$

Whole valves of marine pelecypods (Hiatella arctica) in coarse sand with some cobbles, associated with delta level at alt $95 \mathrm{ft}$.

General Comment (D.M.B.): the 3 dates, with date on shells at alt 165 ft (I-1932, $7940 \pm$ 130, Andrews, 1967; cf. Comment under GSC-556, $7740 \pm 140$, GSC VI, date on shells from outer Clyde Inlet), illustrate decreasing rate of land emergence with time at head of Clyde Inlet. For GSC-584 NaOH-leach omitted from sample pretreatment; sample mixed with dead gas for counting. Dates GSC-583 and GSC-631 each based on one 3-day count.

\section{Sam Ford Fiord series, Baffin Island}

Marine molluscs from 2 sites in inner Sam Ford Fiord, Baffin Island, Northwest Territories. Coll. 1965 by J. E. Smith, Geog. Branch, Ottawa.

\section{GSC-630. Sam Ford Fiord, $175 \mathrm{ft}$}

$8000 \pm 150$

Whole valves and fragments of marine pelecypods in horizontal position in silt and clay, ca. $3 \mathrm{mi} \mathrm{NNE}$ of head of Sam Ford Fiord, Baffin Island $\left(70^{\circ} 03^{\prime} \mathrm{N}\right.$ Lat, $71^{\circ} 29^{\prime} \mathrm{W}$ Long), at alt ca. $175 \mathrm{ft}$. Shells coll. at $1 \mathrm{ft}$ depth.

\section{GSC-633. Sam Ford Fiord, $165 \mathrm{ft}$}

$$
\begin{aligned}
& 6270 \pm 150 \\
& 4320 \text { B.C. }
\end{aligned}
$$

Marine molluscs, not in situ, from 10 in. below surface in gully in clay ca. $14.5 \mathrm{mi}$ NNE of head of Sam Ford Fiord, Baffin Island $\left(70^{\circ} 12^{\prime}\right.$ $\mathrm{N}$ Lat, $71^{\circ} 20^{\prime} \mathrm{W}$ Long), at alt ca. $165 \mathrm{ft}$.

General Comment (J.E.S.): both samples are contained in materials supposedly pushed by ice during readvance. However, comparison with other dates obtained from Sam Ford Fiord suggests samples GSC-630 
and GSC-633 probably were interchanged in field; i.e., GSC-633 is not compatible with I-1553 (7500 \pm 200 , Isotopes V), shells from alt ca. 205 ft $14.5 \mathrm{mi}$ NNE from fiord head ( $3 \mathrm{ft}$ below outwash delta on distal side of lateral moraine), as shells are interpreted as either contemporaneous with culmination of advance (to Terminal Stage 1 of Smith, 1966) and building of moraine, or as plowed up during readvance to present position of moraine (Falconer et al., 1965). Likewise, GSC-630 is not compatible with I-1556 $(6240 \pm 140$, Isotopes V) at alt ca. $150 \mathrm{ft} 1.0$ $\mathrm{mi} S$ of fiord head. Both samples mixed with dead gas for counting. Date for GSC-630 based on one 3-day count.

\section{GSC-452. Holder Hills, Ellesmere Island}

$1380 \pm 130$

Bone from whale skull on beach near Holder Hills, Ellesmere Island $\left(78^{\circ} 54^{\prime} \mathrm{N}\right.$ Lat, $85^{\circ} 10^{\prime} \mathrm{W}$ Long) at alt ca. $8 \mathrm{ft}$. Coll. 1962 by W. O. Kupsch, J. C. Sproule Assocs. Comment (W.O.K.): assuming dead whale stranded on shore, date records late phase of marine inundation and average uplift during last $1400 \mathrm{yr}$ of ca. $0.6 \mathrm{ft} / 100 \mathrm{yr}$. Two fractions were dated:

$$
\begin{array}{lr}
\text { collagen fraction } & 1380 \pm 130 \\
\text { inorganic fraction } & 450 \pm 130
\end{array}
$$

\section{GSC-745. Macdonald River, Ellesmere Island (shells) $\mathbf{3 7 5 0} \pm \mathbf{\text { B.c. }}$

Marine pelecypod shells (Hiatella arctica and Mya truncata) from surface of silt exposed $1 \mathrm{mi} \mathrm{S}$ of Macdonald R. delta, at head of Tanquary Fiord, Ellesmere Island, Northwest Territories $\left(81^{\circ} 24^{\prime} \mathrm{N}\right.$ Lat, $76^{\circ}$ $55^{\prime}$ W Long), at alt $42 \pm 2$ ft. Coll. 1964 by G. Hattersley-Smith, Defence Res. Board, Ottawa. Comment (G. H-S.): dates gives point on uplift curve for area, which suggests that from 6500 to 5000 yr ago isostatic uplift was ca. $11.5 \mathrm{ft} / 100 \mathrm{yr}$, and subsequently averaged ca. $1 \mathrm{ft} / 100 \mathrm{yr}$ (HattersleySmith and Long, 1967). Date based on one 3-day count.

\section{GSC-722. Truro Island, McDougall Sound \\ $9160 \pm 160$}

Shell fragments of surface on $\mathrm{E}$ side Truro Islat $\left(75^{\circ} 19^{\prime} \mathrm{N} \mathrm{Lat}, 97^{\circ} 10^{\prime} \mathrm{W}\right.$ Long), at alt ca. $350 \mathrm{ft}$. Coll. 1964 by J. G. Fyles for W. Blake, Jr. Comment (W.B., Jr.): date, on shells close to limit of marine submergence, is minimum for time of deglaciation of N McDougall Sound, between Cornwallis and Bathurst Islands.

\section{GSC-724. Cockscomb Peak, Bathurst Island}

$9230 \pm 280$

Shell fragments, mainly Hiatella arctica, from ground surface on ridge of Cockscomb Peak, E Bathurst Island, Northwest Territories $\left(76^{\circ}\right.$ $11^{\prime} \mathrm{N}$ Lat, $97^{\circ} 35^{\prime} \mathrm{W}$ Long), at alt ca. $350-365 \mathrm{ft}$. Coll. 1964 by W. Blake, Jr. Comment (W.B., Jr.): as shells are assumed to be close to marine 
limit, date is minimum for deglaciation. Sample mixed with dead gas for counting; date based on three 1-day counts.

\section{GSC-726. Walker River, Bathurst Island}

$$
8090 \pm 150
$$

6140 B.c.

Fragments of shells, mainly Hiatella arctica and Mya truncata, from surface of stony silt on S side of Walker R., ca. $3 \mathrm{mi} \mathrm{W}$ of Driftwood Bay, Bathurst Island, Northwest Territories ( $75^{\circ} 57^{\prime} \mathrm{N}$ Lat, $97^{\circ} 52^{\prime} \mathrm{W}$ Long), at alt ca. $260 \mathrm{ft}$. Coll. 1963 by W. Blake, Jr. Comment (W.B., Jr.): shells are in thin silt overlying peat, surface sample of which is $7100 \pm 140$ yr old (GSC-201, GSC IV); at ca. $300 \mathrm{ft}$ alt, close to marine limit, shells are $9600 \pm 210 \mathrm{yr}$ old (GSC-174, GSC IV). Shells and enclosing stony silt apparently represent colluvium deposited over peat. Date must be reconciled with GSC-174 which possibly was contaminated by "old" shells redeposited from higher alt (cf. Blake, 1964); or possibly GSC-726 was contaminated in unknown way by younger material.

\section{GSC-692. Young Inlet, Bathurst Island}

$9570 \pm 140$

7620 B.c.

Shell fragments of Mya truncata from surface of silt $3 \mathrm{mi}$ SE of head of Young Inlet, Bathurst Island, Northwest Territories $\left(76^{\circ} 24.5^{\prime} \mathrm{N}\right.$ Lat, $98^{\circ} 44^{\prime} \mathrm{W}$ Long), at alt ca. 360 to $370 \mathrm{ft}$. Coll. 1963 by W. Blake Jr. Comment (W.B., Jr.): date on shells within $100 \mathrm{ft}$ of marine limit confirms GSC-251 (9690 \pm 140 , GSC VI); coll. $12.5 \mathrm{mi}$ to NE; together dates indicate NE corner of Bathurst Inlet was deglaciated by ca. 9600 yr B.P. Date based on one 3-day count.

\section{GSC-738. Morshead Point, Bathurst Island}

$7660 \pm 140$

Shell fragments of Mya truncata from surface of sand deposit, E side of outlet gorge from unnamed lake, $1 \mathrm{mi}$ SW of Morshead Point,

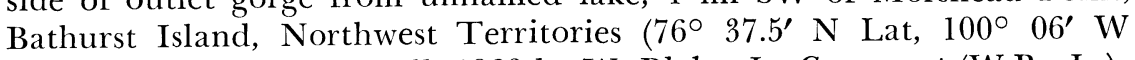
Long), at alt ca. $115 \mathrm{ft}$. Coll. 1963 by W. Blake, Jr. Comment (W.B., Jr.): area was deglaciated ca. $9200 \mathrm{yr}$ ago (GSC-182, $9240 \pm 160$, GSC IV; Blake, 1964). Date, on shells slightly above present lake, indicates lake was arm of sea for at least $1500 \mathrm{yr}$. Date based on one 3-day count.

\section{GSC-721. Massey Island}

$9750 \pm 160$

7800 B.c.

Shell fragments, mainly marine pelecypod Hiatella arctica, from ground surface on flat ridgetop, NE part of Massey Island, Northwest Territories $\left(76^{\circ} 05^{\prime} \mathrm{N}\right.$ Lat, $102^{\circ} 33^{\prime} \mathrm{W}$ Long), at alt ca. $350 \mathrm{ft}$. Coll. 1964 by W. Blake, Jr. Comment (W.B., Jr.): shells coll. close to marine limit. Date is minimum for deglaciation and is similar to GSC-249 (9780 \pm 190 , GSC VI), on shells at same alt from Schomberg Point, westernmost Bathurst Island. Sample mixed with dead gas for counting.

\section{Winter Harbour Moraine series II, Melville Island}

Winter Harbour moraine on S coast of Melville Island, Northwest 
Territories, marks stand of NW margin of Laurentide Ice Sheet, probably at local maximum during classical Wisconsin (Fyles, 1967). Shellbearing marine deposits occur up to ca. $200 \mathrm{ft}$ alt on the inland (distal) side of moraine and below $100 \mathrm{ft}$ on seaward (proximal) side. Dates on marine shells coll. 1966 by J. G. Fyles supplement those in GSC VI.

GSC-727. "Pale" till

Fragments of shells (Hiatella arctica) from degraded surface of "pale" till, alt $260 \mathrm{ft}, 0.5 \mathrm{mi} \mathrm{NW}$ of distal margin of Winter Harbour moraine at $74^{\circ} 47^{\prime} \mathrm{N}$ Lat, $110^{\circ} 52^{\prime} \mathrm{W}$ Long. "Pale" till is older than moraine and possibly pre-Wisconsin. Comment (J.G.F.): shells represent either marine submergence younger than till or glacially transported material incorporated in till. Sample mixed with dead gas for counting.

\section{GSC-787. "Old" till}

$42,400 \pm 1900$

Fragments of Hiatella arctica from shallow slide scar at $74^{\circ} 38.5^{\prime}$ $\mathrm{N}$ Lat, $110^{\circ} 51^{\prime} \mathrm{W}$ Long, alt $280 \mathrm{ft}$, in till adjacent to distal margin of Winter Harbour moraine and apparently older than moraine. Comment (J.G.F.): enclosing till is probably equivalent to "pale" till on which GSC-727 (>33,000, this series) was coll. Two fractions were dated separately after removal of outer $20 \%$ of shells; both dates probably are minimal:

outer fraction (21 to $60 \%$ leach), two 1-day counts $33,800 \pm 900$ inner fraction (61 to $100 \%$ leach), one 3-day count $42,400 \pm 1900$

\section{GSC-667. Moraine crest}

Fragments of Hiatella arctica from bouldery surface on top of Winter Harbour moraine, alt $>200 \mathrm{ft}$, but $<300 \mathrm{ft}$ (from contour map), at $74^{\circ} 56^{\prime} \mathrm{N}$ Lat, $110^{\circ} 46^{\prime} \mathrm{W}$ Long. Shells probably transported onto moraine by Laurentide ice from source to SW beneath Viscount Melville Sound. Comment (J.G.F.): Two fractions were dated separately after removal of outer $20 \%$ of shells:

outer fraction (21 to $60 \%$ leach), two 1-day counts $26,700 \pm 450$

inner fraction (61 to $100 \%$ leach), one 3-day count $\quad 27,790 \pm 480$ Similarity of dates on inner and outer fractions suggests no major contamination and possible representation of approx. absolute age rather than minimum ages.

\section{GSC-664. Cape Providence}

$$
\begin{aligned}
& 11,310 \pm 150 \\
& 9360 \text { в.C. }
\end{aligned}
$$

Hiatella arctica from highest shell-bearing beds in horizontally stratified silt and clay to bedrock hillside ca. $4 \mathrm{mi} \mathrm{NE}$ of Cape Providence (74 $26^{\prime} \mathrm{N}$ Lat, $112^{\circ} 11^{\prime} \mathrm{W}$ Long). Site is beyond SW end of NE-SW trending Winter Harbour moraine but apparently bears distal relation to it. Comment (J.G.F.): date probably relates to narrow marine embayment developed between bedrock hillside and Laurentide ice front at 
Winter Harbour moraine; sample occurrence is comparable to GSC-278 $(10,340 \pm 140$, GSC VI), ca. $25 \mathrm{mi}$ to $\mathrm{NE}$ along distal side of moraine. Cf. also GSC-363, 10,900 \pm 160 (GSC VI) and GSC-786, 10,900 \pm 150 (this series) from distal part of moraine near GSC-278. Date based on one 3-day count.

\section{GSC-786. Distal Ridge}

$10,900 \pm 150$ 8950 B.c.

Fragments of Hiatella arctica from stony sandy crest (alt $260 \mathrm{ft}$ ) of narrow ridge forming distal margin of Winter Harbour moraine at $74^{\circ} 43.5^{\prime} \mathrm{N}$ Lat, $110^{\circ} 53^{\prime} \mathrm{W}$ Long. Comment (J.G.F.): shells incorporated into till of moraine ridge by minor ice-marginal fluctuations which picked up penecontemporaneous marine material equivalent to GSC-664 $(11,310 \pm 150$, this series) and GSC-278 (10,340 \pm 150 , GSC VI). Occurrence is comparable to GSC-363 (10,900 \pm 160 , GSC VI). Outer $50 \%$ of shells removed before dating. Date based on one 3-day count.

\section{GSC-665. Delta}

$9620 \pm 150$

Shells and fragments of Hiatella arctica from eroded surface of silty sand 10 to $15 \mathrm{ft}$ below surface of delta (alt $80 \mathrm{ft}$ ) at Winter Harbour $\left(74^{\circ} 47.5^{\prime} \mathrm{N}\right.$ Lat, $110^{\circ} 41^{\prime} \mathrm{W}$ Long). Comment (J.G.F.): site is within ca. $30 \mathrm{ft}$ of local marine limit on proximal side of Winter Harbour moraine; date is minimum for retreat of Laurentide ice from moraine. Occurrence is comparable to GSC-339 (9550 \pm 160 , GSC VI), shells from proximal side of moraine $\mathrm{W}$ of Hearne Point.

\section{GSC-854. Satellite Bay, Prince Patrick Island}

$7090 \pm 150$

Organic debris from $6 \mathrm{ft}$ depth in layer parallel with surface on $\mathrm{N}$ side of elongate pingo, $11.5 \mathrm{mi} \mathrm{SW}$ of Cape Krabbe and $0.9 \mathrm{mi}$ from coast on $\mathrm{N}$ bank of river flowing into head of Satellite Bay, Prince Patrick Island, Northwest Territories ( $77^{\circ} 22^{\prime} \mathrm{N}$ Lat, $116^{\circ} 35^{\prime} \mathrm{W}$ Long), at alt ca. $12 \mathrm{ft}$. Sample buried through melting of upper part of underlying ice wedge, and subsequent downslope movement of material into resulting depression; excavation in frozen ground accomplished by pumping water. Coll. 1966 by A. Pissart, Univ. of Liège, Liège, Belgium. Comment (A.P.): melting ice wedge and accumulation of organic debris postdates development of pingo; i.e., sea withdraw from site and pingo developed more than 7100 yr ago. NaOH-leach omitted from sample pretreatment.

\section{GSC-764. Intrepid Inlet, Prince Patrick Island}

Organic debris from continuous, nearly horizontal layer at 5 to $9 \mathrm{ft}$ depth (surface slope 220), $14.5 \mathrm{mi}$ NNW of Salmon Point and 3.3 mi W of Intrepid Inlet, Prince Patrick Island, Northwest Territories $\left(76^{\circ} 42^{\prime} \mathrm{N}\right.$ Lat, $118^{\circ} 39^{\prime} \mathrm{W}$ Long), at alt $100 \mathrm{ft}$. Organic layer is thin 
soil with vegetation in growth position, overlain by slope deposits of sand in which ice-wedges have developed. Sequence is contained in Nfacing nivation hollow; excavation in frozen material was accomplished by pumping water. Coll. 1966 by A. Pissart. Comment (A.P.): date indicates slow slope evolution, that nivation hollow is more than $9700 \mathrm{yr}$ old, and that ice-wedges in overlying sand have formed since. Date also is minimum for deglaciation; comparison with GSC-260 (11,160 \pm 150 , GSC VI), date on marine shells in silt and sand beneath delta terrace at alt $100 \mathrm{ft}$, on $\mathrm{E}$ side of Intrepid Inlet, indicates both nivation hollow and soil developed soon after deglaciation and/or emergence. $\mathrm{NaOH}$ leach omitted from sample pretreatment.

Date lists:
GSC I
GSC II
GSC III
GSC IV
GSC V
GSC VI
Isotopes I
Isotopes II
Isotopes V
RIKEN III
Saskatchewan II
Saskatchewan III
Saskatchewan IV
USGS VII
Yale II
Yale V

\title{
REFERENCES
}

\author{
Dyck and Fyles, 1962 \\ Dyck and Fyles, 1963 \\ Dyck and Fyles, 1964 \\ Dyck, Fyles, and Blake, 1965 \\ Dyck, Lowdon, Fyles, and Blake, 1966 \\ Lowdon, Fyles, and Blake, 1967 \\ Walton, Trautman, and Friend, 1961 \\ Trautman and Walton, 1962 \\ Trautman and Willis, 1966 \\ Yamasaki, Hamada, and Fujiyama, 1967 \\ McCallum and Dyck, 1960 \\ McCallum and Wittenberg, 1962 \\ McCallum and Wittenberg, 1965 \\ Ives, Levin, Robinson, and Rubin, 1964 \\ Preston, Person, and Deevey, 1955 \\ Stuiver, Deevey, and Gralenski, 1960
}

Andrews, J .T., 1966, Pattern of coastal uplift and deglacierization, West Baffin Island, N.W.T.: Canada, Geog. Branch, Geog. Bull., v. 8, p. 174-193.

1967, Radiocarbon dates obtained through Geographical Branch field observations: Canada, Geog. Branch, Geog. Bull., v. 9, p. 115-162.

Armstrong, J. E., Crandell, D. R., Easterbrook, D. J., and Noble, J. B., 1965, Late Pleistocene stratigraphy and chronology in southwestern British Columbia and northwestern Washington: Geol. Soc. America Bull., v. 76, p. 321-330.

Blake, Weston, Jr., 1963, Notes on glacial geology, northeastern District of Mackenzie: Canada, Geol. Survey Paper 63-28, 12 p. 1964, Preliminary account of the glacial history of Bathurst Island, Arctic
Archipelago: Canada, Geol. Survey Paper 64-30, 8 p.

special 1966, End moraines and deglaciation chronology in northern Canada, with

Borns, H. W., Jr., 1967, Field trip guidsand: Canada, Geol. Survey Paper, 66-26, 31 p. 30th Annual Reunion, May 20-21, 19 p.

Bostock, H. S., 1952, Geology of northwest Shakwak Valley, Yukon Territory: Canada, Geol. Survey Mem. 267, 54 p.

1966, Notes on glaciation in central Yukon Territory: Canada, Geol. Survey Paper 65-36, 18 p.

Craig, B. G., 1961, Surficial geology of northern District of Keewatin, Northwest Territories: Canada, Geol. Survey Paper 61-5, 8 p.

1965 , Notes on moraines and radiocarbon dates in northwest Baffin Island, Melville Peninsula, and northeast District of Keewatin: Canada, Geol. Survey Paper 65-20, 7 p.

Deevey, E. S., 1958, Radiocarbon-dated pollen sequences in eastern North America, in Verhandl. der vierten Internationalen Tagung der Quartärbotaniker 1957: Veröff, Geobotanisches Inst. Rübel in Zürich, Heft 34, p. 30-37.

Dreimanis, Aleksis, 1961, Postglacial mastodon remains at Tupperville, Ontario: in Geol. Soc. America Program of Annual Meetings, p. 42A. Also in Geol. Soc. America Spec. Paper 68, 1962, p. 167. 
Dreimanis, Aleksis, 1967, Mastodons, their geologic age and extinction in Ontario, Canada: Canadian Jour. Earth Sci., v. 4, p. 663-675.

Dreimanis, Aleksis, Terasmae, Jaan, and McKenzie, G. D., 1966, The Port Talbot Interstade of the Wisconsin Glaciation: Canadian Jour. Earth Sci., v. 3, p. 305-325.

Dyck, Willy and Fyles, J. G., 1962, Geological Survey of Canada radiocarbon dates I: Radiocarbon, v. 4, p. 13-26.

1963, Geological Survey of Canada radiocarbon dates II: Radiocarbon, v. 5 , p. $39-55$. v. 6, p. $167-181$.

Dyck, Willy, Fyles, J. G., and Blake, W., Jr., 1965, Geological Survey of Canada radiocarbon dates IV: Radiocarbon, v. 7, p. 24-46.

Dyck, Willy, Lowdon, J. A., Fyles, J. G., and Blake, W., Jr., 1966, Geological Survey of Canada radiocarbon dates V: Radiocarbon, v. 8, p. 96-127.

Elson, J. A., 1967, Geology of Glacial Lake Aggasiz, in Mayer-Oakes, W. J., ed., Life, Land and Water; Proceedings of the 1966 Conference on Environmental Studies of the Glacial Lake Agassiz Region: Occasional Papers, Dept. of Anthropology, Univ, of Manitoba, no. 1: Winnipeg, Univ. of Manitoba Press, p. 37-95.

Falconer, George, Ives, J. D., Løken, O. H., and Andrews, J. T., 1965, Major end moraines in eastern and central Arctic Canada: Canada, Geog. Branch, Geog. Bull., v. 7, p. 137-153.

Fernald, A. T., 1962, Radiocarbon dates relating to a widespread volcanic ash deposit, eastern Alaska, in: U. S. Geol. Survey Prof. Paper 450-B, p. B29-30.

Fulton, R. J., Olympia Interglaciation, Purcell trench, British Columbia: Geol. Soc. America Bull. (in press)

Fyles, J. G., 1967, Winter Harbour Moraine, Melville Island: in Report of Activities, Part A: May to October 1966: Canada, Geol. Survey Paper 67-1, Part A, p. 8-9.

Geological Association of Canada, 1958, Glacial Map of Canada; Geol. Assoc. Canada.

Hattersley-Smith, G. and Long, A., 1967, Post-glacial uplift at Tanquary Fiord. northern Ellesmere Island, N.W.T.: Arctic, v. 20, p. 255-260.

Hughes, O. L. and Terasmae, Jaan, 1963, SIPRE ice-corer for obtaining samples from permanently frozen bogs: Arctic, v. 16, p. 270-272.

Ives, P. C., Levin, Betsy, Robinson, R. D., and Rubin, Meyer, 1964, U. S. Geological Survey radiocarbon dates VII: Radiocarbon, v. 6, p. 37-76.

Johnston, W. A., 1915, Rainy River district, Ontario, surficial geology and soils: Canada, Geol. Survey Memoir 82, 123 p.

Klassen, R. W., 1967, Stratigraphy and chronology of Quarternary deposits of Assini boine River valley and its tributaries, in Report of Activities, Part B: November 1966 to April 1967: Canada, Geol. Survey Paper 67-1, Part B, p. 55-60.

Lasalle, Pierre, 1966, Late Quaternary vegetation and glacial history in the St. Law rence Lowlands, Canada: Leidse Geologische Mededelingen, v. 38, p. 91-128.

Lewis, C. F. M. and McNeely, R. N., 1967, Survey of Lake Ontario bottom deposits: Proc. 10th Conf. Great Lakes Research, Great Lakes Res. Div., Univ. of Michigan, p. $133-142$.

Livingstone, D. A., 1968, Some interstadial and postglacial pollen diagrams from eastern Canada: Ecological Monographs, v. 38, (in press).

Livingstone, D. A. and Estes, A. H., 1967, A carbon-dated pollen diagram from the Cape Breton plateau, Nova Scotia: Canadian Jour. Botany, v. 45, p. 339-359.

Lowdon, J. A., Fyles, J. G., and Blake, W. Jr., 1967, Geological Survey of Canada radiocarbon dates VI: Radiocarbon, v. 9, p. 156-197.

Matthews, Barry, 1966, Radiocarbon dated postglacial land uplift in northern Ungava, Canada: Nature, v. 211, p. 1164-1166. Canada: 1967, Late Quaternary land emergence in northern Ungava, Quebec: Arctic, v. 20, p. 176-202.

McCallum, K. J. and Dyck, Willy, 1960, University of Saskatchewan radiocarbon dates II: Am. Jour. Sci. Radioc. Supp., v. 2, p. 73-81.

McCallum, K. J. and Wittenberg, J., 1962, University of Saskatchewan radiocarbon dates III: Radiocarbon, v. 4, p. 71-80.

1965, University of Saskatchewan radiocarbon dates IV: Radiocarbon, v. 7, p. $229-235$.

Mott, R. J., 1966, Quarternary palynological sampling techniques of the Geological Survey of Canada: Canada, Geol. Survey Paper 66-41, 24 p.

Nasmith, H., Mathews, W. H., and Rouse, G. E., 1967, Bridge River ash and some other recent ash beds in British Columbia: Canadian Jour. Earth Sci., v. 4, p. 163-169. 
Parizek, R. R., 1964, Geology of the Willow Bunch Lake Area (72-H), Saskatchewan: Saskatchewan Res. Council, Geol. Div., Rept. No. 4, 47 p.

Preston, R. S., Person, Elaine, and Deevey, E. S., 1955, Yale natural radiocarbon measurements II: Science, v. 122, p. 954-960.

Smith, J. E., 1966, Sam Ford Fiord: A study of deglaciation, M.Sc. Thesis, Dept. of Geog., McGill Univ., 93 p.

St-Onge, D. A., 1967, Surficial geology, Iosegun Lake, East half: Canada Geol. Survey Map 15-1966.

Stuiver, Minze, Borns, H. W., Jr., and Denton, G. H., 1964, Age of a widespread layer of volcanic ash in the southwestern Yukon Territory: Arctic, v. 17, p. 259-261.

Stuiver, Minze, Deevey, E. S., and Gralenski, L. J., 1960, Yale natural radiocarbon measurements V: Am. Jour. Sci. Radioc. Supp., v. 2, p. 49-61.

Terasmae, Jaan and Hughes, O. L., 1960, Glacial retreat in the North Bay area, Ontario: Science, v. 131, p. 1444-1446.

Terasmae, Jaan and Lasalle, Pierre, 1968, Notes on late-glacial palynology and geochronology at St. Hilaire, Quebec: Canadian Jour. Earth Sci., v. 5, p 249-257.

Trautman, M. A. and Walton, Alan, 1962, Isotopes, Inc. radiocarbon measurements II: Radiocarbon, v. 4, p. 35-42.

Trautman, M. A. and Willis, E. H., 1966, Isotopes, Inc. radiocarbon measurements $\mathrm{V}$ : Radiocarbon, v. 8, p. 161-203.

Vernon, Peter and Hughes, O. L., 1966, Surficial geology, Dawson, Larsen Creek, and Nash Creek map-areas, Yukon Territory: Canada, Geol. Survey Bull. 136, 25 p.

Walton, Alan, Trautman, M. A., and Friend, J. P., 1961, Isotopes, Inc. radiocarbon measurements I: Radiocarbon, v. 3, p. 47-59.

Westgate, J. A., 1965, The pleistocene stratigraphy of the Foremost-Cypress Hills area, Alberta, in Guidebook, 15th Ann. Field Conf., Alberta Soc. of Petroleum Geologists, p. 85-111.

Westgate, J. A. and Dreimanis, Aleksis, 1967, Volcanic ash layers of recent age at Banff National Park, Alberta, Canada: Canadian Jour. Earth Sci., v. 4, p. 155-161.

Yamasaki, Fumio, Hamada, Tatsuji, and Fujiyama, Chikako, 1967, RIKEN natural radiocarbon measurements III: Radiocarbon, v. 9, p. 301-308. 